O PRIMEIRO

SACRAMENTO

- BATISMOS DE ESCRAVOS EM IGUAPE

(1811-1850)

Contatos

Agnaldo Valentin Av. Arlindo Béttio, 1000 03828-000 - São Paulo - São Paulo E-mail: guiligui@usp.br

José Flávio Motta Av. Prof. Luciano Gualberto, 908 Edifício FEA 2 - sala 234 05508-900 - São Paulo - São Paulo E-mail: jflaviom@usp.br

\section{Agnaldo Valentin*}

Universidade de São Paulo

José Flávio Motta**

Universidade de São Paulo

\title{
Resumo
}

Com base em registros de batismo de crianças escravas e nas listas nominativas de habitantes, estudamos diversas características desse primeiro sacramento católico. A partir do cruzamento nominativo dessas fontes, nossa atenção está nos batismos, nos infantes batizados, em seus pais, padrinhos e proprietários, tomados sobre o pano de fundo do dinamismo da rizicultura em Iguape, São Paulo, no Vale do Ribeira.

\section{Palavras-chave}

Batismos de escravos-rizicultura em Iguape-economia edemografia da escravidão.

* O autor é doutor em História pelo Departamento de História da Faculdade de Filosofia, Letras e Ciências Humanas da Universidade e professor doutor da Escola de Artes, Ciências e Humanidades.

** O autor é doutor em Economia, professor associado-3 e livre-docente da Faculdade de Economia, Administração e Contabilidade, no Departamento de Economia. 
rev. hist. (São Paulo), n. 171, p. 141-174, jul.-dez., 2014 http://dx.doi.org/10.11606/issn.2316-9141.rh.2014.89010

\title{
THE FIRST
}

SACRAMENT -

BAPTISMS OF SLAVES

IN IGUAPE

(1811-1850)

Agnaldo Valentin Av. Arlindo Béttio, 1000 03828-000 - São Paulo - São Paulo E-mail: guiligui@usp.br

José Flávio Motta Av. Prof. Luciano Gualberto, 908 Edifício FEA 2 - sala 234 05508-900 - São Paulo - São Paulo E-mail: jflaviom@usp.br

\section{Agnaldo Valentin}

Universidade de São Paulo José Flávio Motta

Universidade de São Paulo

\begin{abstract}
We study baptisms of slaves. Our focus is on baptized children, their parents, their godparents and their owners, in the context of the economic dynamism based on rice cultivation in Iguape, Vale do Ribeira, in São Paulo. Our sources are parish registers of baptisms and nominative manuscript censuses ("listas nominativas de habitantes"). The analysis is based on nominative crosschecking of these documents.
\end{abstract}

\section{Keywords}

Baptisms of slaves - rice cultivation in Iguape - economy and demography of slavery. 
rev. hist. (São Paulo), n. 171, p. 141-174, jul.-dez., 2014 http://dx.doi.org/10.11606/issn.2316-9141.rh.2014.89010
Agnaldo Valentin e José Flávio Motta

0 primeiro sacramento - batismos de escravos em lguape (1811-1850)

\section{Introdução}

O cruzamento nominativo de fontes tem sido recomendado por todos e posto em prática por vários estudiosos da escravidão no Brasil. No que respeita aos temas suscitados pelo sacramento do batismo, entre eles o do apadrinhamento de crianças cativas, encontramos tal recomendação, por exemplo, como a principal mensagem constante de um breve e interessante balanço da produção historiográfica brasileira, elaborado por Carlos Bacellar. ${ }^{1}$ Nosso artigo traz uma contribuição em termos do cruzamento nominativo mencionado. Confrontamos as informações extraídas dos registros paroquiais de batismos com aquelas disponíveis nas listas nominativas de habitantes. E nos preocupamos com a convergência entre os informes coletados nessas fontes distintas. Realizamos um esforço de análise que sofre as inevitáveis vicissitudes postas, em especial, pelas características inerentes às populações abertas e com elevada mobilidade espacial, bem como pelo evolver do tráfico atlântico de cativos, cuja extinção foi decretada em inícios da década de 1830, porém concretizada tão-somente cerca de vinte anos depois.

Nossa atenção recai sobre os batismos das crianças escravas nascidas em Iguape entre 1811 e 1850. O povoamento inicial dessa localidade paulista ocorrera há muito, entre fins do século XVI e inícios do XVII, ${ }^{2}$ e, em 1849, a Vila de Nossa Senhora das Neves de Iguape foi elevada à categoria de cidade. A primeira metade dos Oitocentos correspondeu, ademais, à etapa de maior dinamismo da rizicultura da região do Vale do Ribeira, onde se situa a localidade em tela. ${ }^{3}$

1 BACELLAR, Carlos de Almeida Prado. Os compadres e as comadres de escravos: um balanço da produção historiográfica brasileira. In: XXVI SIMPÓSIO NACIONAL DE HISTÓRIA - ANPUH. Anais. São Paulo, 2011. Disponível em: <http://www.snh2011.anpuh.org/resources/anais/14/1307925540_ ARQUIVO_Oscompadreseascomadresdeescravos.pdf>. Acesso em: 07/02/2013.

2 Manuel Eufrásio de Azevedo Marques, por exemplo, escreveu: "É desconhecida a época de sua fundação. Alguns historiadores a assinalam em 1567, outros em 1579, outros em 1611, e outros, finalmente, em 1654, pelo capitão Eleodoro Ébano Pereira; o que, porém, pudemos descobrir em documentos autênticos é que já era vila em 1638 e que a sua primeira matriz foi concluída em 1635". (MARQUES, Manuel Eufrásio de Azevedo. Apontamentos históricos, geográficos, biográficos, estatísticos e noticiosos da Província de São Paulo, seguidos da cronologia dos acontecimentos mais notáveis desde a fundação da Capitania de São Vicente até o ano de 1876. São Paulo: Comissão do IV Centenário da Cidade de São Paulo, 1953, v. 1, p. 321).

3 Agnaldo Valentin estudou a produção e a comercialização do arroz no Vale do Ribeira durante o século XIX e sugeriu a adoção de uma periodização segmentada em três intervalos: "o primeiro, que vai de 1800 a 1840, correspondeu à fase de gênese e expansão da rizicultura (...); o segundo, de 1841 a 1860, grosso modo, foi o período com as maiores quantidades exportadas do grão (...) e o último (1861 a 1880), que se caracterizou pela estabilidade econômica 
rev. hist. (São Paulo), n. 171, p. 141-174, jul.-dez., 2014 http://dx.doi.org/10.11606/issn.2316-9141.rh.2014.89010
Agnaldo Valentin e José Flávio Motta

0 primeiro sacramento - batismos de escravos em Iguape (1811-1850)

Dividimos a análise em duas partes. Na primeira, apresentamos algumas tabulações mais gerais a partir do conjunto coletado de assentos de batismos. Beneficiária do aumento do preço do arroz e do intenso ritmo do tráfico atlântico de escravos, a população cativa de Iguape praticamente triplicou entre 1801 e 1836, de 711 para 2.035 pessoas. ${ }^{4}$ Todavia, parte expressiva desse crescimento decorreu da capacidade reprodutiva da escravaria, conforme veremos adiante com base nas tabulações aludidas. Na segunda parte do artigo, adotamos o ano de 1828 como ponto de clivagem. Para esse ano, utilizamos a lista nominativa de habitantes como referência de mão dupla: buscamos, nos registros de batismo, as crianças escravas com menos de 10 anos identificadas na lista e, concomitantemente, procuramos, no arrolamento nominativo, nas escravarias de seus senhores ou, eventualmente, nas posses de seus herdeiros, todos os cativos dos proprietários recenseados batizados entre 1811 e 1828.

\section{Os registros de batismos em Iguape}

No gráfico 1, apresentamos as médias móveis trienais do total de registros, bem como sua partição segundo legitimidade. Evidencia-se o provável impacto negativo, sobre a quantidade de assentos de batismo, das discussões em torno da Lei de 7 de novembro de $1831 .{ }^{5}$ Notamos, não obstante tal im-

e pela redução acentuada da força de trabalho escrava". VALENTIN, Agnaldo. Uma civilização do arroz: agricultura, comércio e subsistência no Vale do Ribeira (1800-1880). Tese de doutorado, História, FFLCH-USP. São Paulo, 2006, p. 65.

4 Cf. Idem, p. 171.

5 A qual "[d]eclara livres todos os escravos vindos de fora do Império, e impõe penas aos importadores dos mesmos escravos". Coleção de Leis do Império do Brasil, 1808-1889. Disponível em: <http://www2.camara.gov.br/legislacao/publicacoes/doimperio>. Acesso em 19/05/2008. Essa lei tornou-se conhecida como Lei Feijó ou, sobretudo, como a lei "para inglês ver"! Todavia, estudos mais recentes têm questionado esse notório entendimento da lei de 1831. Entre outros, citemos, por exemplo, o dossiê organizado pelas historiadoras Beatriz Mamigonian e Keila Grinberg, que ocupou em 2007 a maior parte dos Estudos Afro-Asiáticos, periódico publicado pela Universidade Cândido Mendes, compondo um volume correspondente a três números da revista naquele ano. MAMIGONIAN, Beatriz Gallotti \& GRINBERG, Keila (orgs.). Dossiê: "Para inglês ver?" Revisitando a Lei de 1831. Estudos Afro-Asiáticos, Rio de Janeiro, ano 29, nº. 1/ 2/ 3, jan./dez. 2007, p. 90-340. De fato, têm sido profícuos os trabalhos dedicados à análise do período de tráfico ilegal, assim denominado o intervalo entre a Lei Feijó e a efetiva extinção do comércio da mercadoria humana pelo Atlântico, extinção esta para a qual foi um marco inconteste a Lei Eusébio de Queiróz, de 1850. Ver, por exemplo: CARVALHO, Marcus Joaquim Maciel de. A repressão do tráfico atlântico de escravos e a disputa partidária nas províncias: os ataques aos desembarques em Pernambuco durante o governo praieiro, 1845-1848. Tempo, Niterói-RJ, v. 14, nº 27, 2009, p. 133-149; LIMA, Carlos Alberto Medeiros. A cana, o café, os 
pacto, uma tendência de crescimento até meados da década de 1830, a partir de quando o número de registros se estabilizou relativamente, ao redor de 75 casos por ano. O aumento e a estabilidade mencionados coincidem com a variação positiva da população escrava na vila litorânea até a quarta década do século XIX. Percebemos, ademais, uma similitude interessante entre a proxi da taxa geral de natalidade de 1836 e a de 1874, sugerindo certa estabilidade desse indicador entre os dois anos referidos. ${ }^{6}$

\section{Gráfico 1}

Número de assentos de batismos (médias móveis trienais). Iguape, 1812-1850

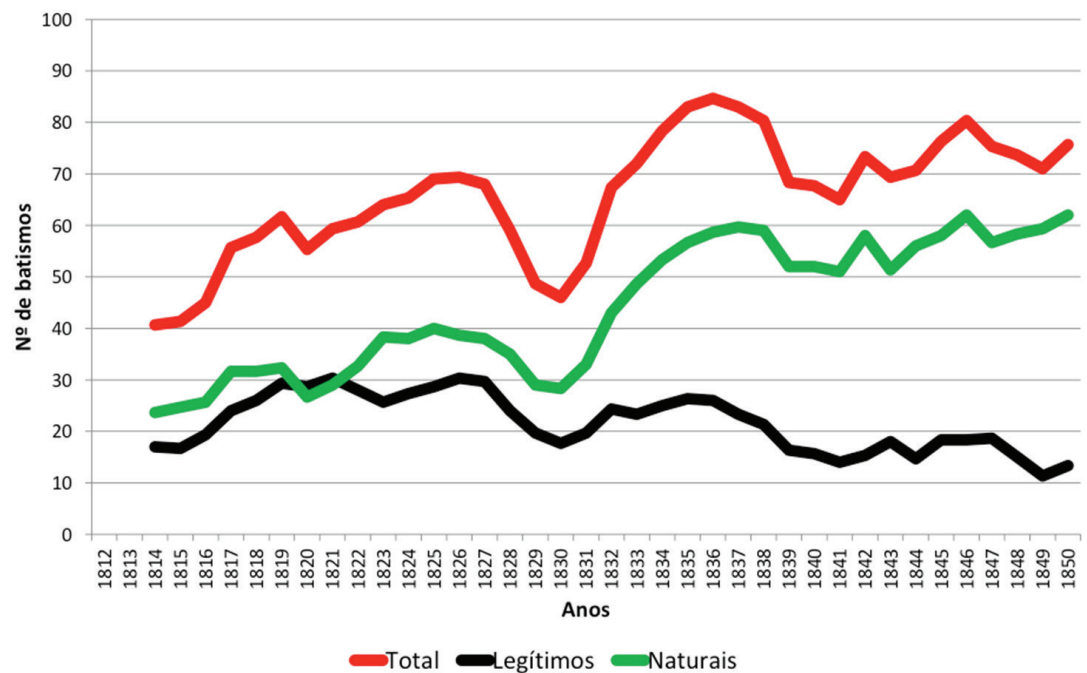

${ }^{1}$ Excluímos 1811 do cômputo das médias móveis trienais pelo fato de os primeiros registros por nós levantados para esse ano datarem de junho.

Fonte: Registros de batismos de Iguape.

alimentos e o tráfico ilegal de escravos para a província de São Paulo. Programa de Seminários em História Econômica "Hermes \& Clio". São Paulo: FEA/USP, junho de 2011. Disponível em: <http:// www.fea.usp.br/feaecon//nucleos_ex.php?i=9E्E=18>; e MAMIGONIAN, Beatriz Gallotti. In: the name of freedom: Slave trade abolition, the law and the Brazilian branch of the African emigration scheme (Brazil-British West Indies, 1830s-1850s). Slavery \& Abolition, v. 30, nº. 1, março 2009, p. 41-66.

6 Os números são os seguintes: em 1836, 76 registros de batismo de crianças cativas e 2.035 escravos na lista nominativa, portanto aproximadamente 373 batizados por 10.000 pessoas; para 1874, as cifras correlatas igualaram 57 e 1.584, portanto, perto de 360 batizados por 10.000 pessoas. Os dados de 1874 foram calculados a partir de MOTTA, José Flávio \& VALENTIN, Agnaldo. Dinamismo econômico e batismo de ingênuos - a libertação do ventre da escrava em Casa Branca e Iguape, Província de São Paulo (1871-1885). Estudos Econômicos, v. 38, n. 2, abr./jun. 2008, p. 215-217. 
rev. hist. (São Paulo), n. 171, p. 141-174, jul.-dez., 2014 http://dx.doi.org/10.11606/issn.2316-9141.rh.2014.89010
Agnaldo Valentin e José Flávio Motta

0 primeiro sacramento - batismos de escravos em Iguape (1811-1850)

O informe da condição de legitimidade não deixa dúvida sobre a importância das crianças nascidas a partir de uniões sacramentadas pela Igreja até o final da década de 1820: em termos relativos, 43,4\%, em média, contra 24,6\%, também em média, entre 1831 e 1850. Esse resultado não é original na historiografia. Por exemplo, Márcia Vasconcellos verificou, em Angra dos Reis, no mesmo período, porcentagens um pouco menores de legítimos (cerca de 35,0\% entre 1805 e 1837), mas com redução significativa no intervalo 1838-1848, para 23,0\%.7 E Sheila de Castro Faria encontrou igualmente, no decorrer dos Oitocentos, "quedas bruscas dos casamentos entre cativos". 8

Não podemos descartar as mudanças dos párocos havidas na vila de Iguape como causa da redução do número de legítimos. De fato, por exemplo, até o ano de 1833, assinava os registros João Crisóstemo de Oliveira Salgado Bueno (41,7\% de legítimos), com ocasional participação de Amaro Antunes da Conceição (em 1820, 52,9\%) e José Alves Carneiro (1827 a 1829, 40,0\%). O período de 1834 a 1838 ficou sob a responsabilidade de João Batista Ferreira (27,7\% de legítimos), retornando José Alves Carneiro entre 1839 e 1848 (21,4\%), assumindo então Antonio Carneiro da Silva Braga (17,3\%). Em que pese o eventual impacto de tais mudanças, é digna de nota a disparidade entre os porcentuais de legítimos computados nos dois intervalos nos quais foi o mesmo pároco, José Alves Carneiro, a assinar os assentos.

Lancemos mão de outra fonte. Na lista nominativa dos habitantes de 1815, casados e viúvos representavam 22,1\% dos escravos com 15 anos ou mais. A dita participação permaneceu praticamente a mesma em 1828 (22,5\%) e sofreu redução relevante em 1836 (para 16,4\%), corroborando os resultados apresentados no gráfico 1 .

De outra parte, foi elevada a correlação (igual a 0,884) entre o número de batismos por escravista (aqui tomado como variável proxi para o tamanho da posse) e o de crianças batizadas legítimas, o que reafirma a observada

\footnotetext{
VASCONCELLOS, Marcia Cristina Roma de. Famílias escravas em Angra dos Reis, 1801-1888. Tese de doutorado em História, FFLCH-USP. São Paulo, 2006, p. 165.

8 E observou, vale a pena frisar: "a diminuição dos casamentos legais entre cativos não significou ausência de família escrava. Significou, isso sim, uma mudança formal, visando a satisfazer interesses senhoriais, ao mesmo tempo em que deixou a cargo dos escravos grande parte da organização da vida no cativeiro". FARIA, Sheila de Castro. A colônia em movimento: fortuna e família no cotidiano colonial. Rio de Janeiro: Nova Fronteira, 1998, p. 126. Na contramão desses resultados, convém apontar, Maísa Faleiros notou em Franca um ligeiro aumento na taxa de legitimidade da primeira para a segunda metade do século XIX, de 44,9\% para 50,9\%. Cf. CUNHA, Maísa Faleiros da. Demografia e família escrava. Franca-SP, século XIX. Tese de doutorado, Demografia, Unicamp. Campinas, 2009, p. 96.
} 
associação entre as maiores escravarias e a maior possibilidade de efetivação de uniões legítimas. De 18 casos de proprietários com pelo menos 10 crianças legítimas batizadas entre os anos de 1811 e 1850, percebemos que a maioria já promovia o batismo dos filhos de suas escravas desde a década de 1810 (cf. tabela 1). Dos 18 escravistas listados, quatro deixaram de batizar até 1835 e 10 desapareceram dos registros de batismos entre 1836 e 1849. Entendemos que, para este último resultado, a morte tenha dado a principal contribuição, implicando a partilha dos bens, fragmentação das posses e possíveis desarranjos nas estruturas familiares escravas, favorecendo o aumento da ilegitimidade.

Tabela 1

Escravistas com 10 ou mais registros de batismos de crianças escravas legítimas. Números absolutos e participação relativa das crianças legítimas no total de batizados. Iguape, 1811-1850

\begin{tabular}{|c|c|c|c|c|}
\hline Proprietário & Anos & 1. Batizados & 2. Legítimos & $(2 / 1) \times 100$ \\
\hline Antonio Borges Diniz & $1811-1850$ & 73 & 54 & 74,0 \\
\hline José Antonio Peniche & $1812-1835$ & 57 & 37 & 64,9 \\
\hline João Dias Batista & $1817-1850$ & 55 & 36 & 65,5 \\
\hline Bartolomeu da Costa Almeida Cruz & $1811-1827$ & 33 & 33 & 100,0 \\
\hline Joaquim Franco da Silva & $1812-1847$ & 43 & 29 & 67,4 \\
\hline Candido Pupo da Rocha & $1820-1850$ & 31 & 26 & 83,9 \\
\hline Francisco Carneiro da Silva Braga & $1816-1847$ & 64 & 26 & 40,6 \\
\hline João Antonio da Costa Mendonça & $1812-1835$ & 32 & 22 & 68,8 \\
\hline Antonio Francisco Gonçalves & $1813-1847$ & 53 & 22 & 41,5 \\
\hline Catarina Eufrásia & 1815-1848 & 30 & 20 & 66,7 \\
\hline Vitorino José Lopes & $1813-1842$ & 45 & 16 & 35,6 \\
\hline Antonio Pinto de Almeida & $1813-1839$ & 23 & 16 & 69,6 \\
\hline Antonio Pupo da Rocha & $1812-1840$ & 21 & 16 & 76,2 \\
\hline Joaquim Francisco de Mendonça & $1821-1850$ & 26 & 15 & 57,7 \\
\hline Antonio Moreira Ramos & $1816-1846$ & 31 & 14 & 45,2 \\
\hline Joaquim Xavier Rodrigues & $1812-1842$ & 21 & 11 & 52,4 \\
\hline Joaquim Raimundo Pupo Ferreira & $1835-1848$ & 14 & 11 & 78,6 \\
\hline José Xavier Rodrigues & $1816-1828$ & 10 & 10 & 100,0 \\
\hline
\end{tabular}

Fonte: Registros de batismos de Iguape. 
Retrocedendo à lista nominativa de 1801, localizamos várias dessas 18 pessoas. Lá figuravam: Antonio Borges Diniz, proveniente "das Ilhas", com cinco escravos; José Antonio Peniche, natural de Peniche, com 21 cativos; Bartolomeu da Costa de Almeida Cruz, do Porto, com sete escravos; Vitorino José Lopes, da Ilha Terceira, sem cativos arrolados naquele ano; Antonio Pinto de Almeida, de Iguape, também com nenhum escravo em 1801; Antonio Moreira Ramos, de Matosinhos, com três cativos; João Antonio da Costa Mendonça, da Ilha do Pico, com 18 escravos (e que posteriormente se estabeleceria em Cananeia). Em suma, praticamente todos eles jovens imigrantes, escravistas de pequeno ou médio porte, ou mesmo ainda sem contar com a posse de cativos na abertura do século XIX.

Há que explicitar o contraponto, aqueles não contemplados pelo recorte feito na tabela 1, vale dizer, os escravistas com menos de 10 registros de batismos de crianças escravas legítimas. Assim, os prováveis herdeiros de José Antonio Peniche, Antonio José Peniche e Ana Maria Alves Peniche apareceram, entre 1825 e 1850, em 58 batismos sendo apenas oito legítimos. As cativas do iguapense Silvestre José de Lima, que em 1815 era proprietário de sete escravos, geraram, entre 1811 e 1850, pelo menos 28 crianças, das quais tão-somente três eram legítimas. O lisboeta Francisco de Oliveira Duarte, com nove cativos em 1815, consta como proprietário em 20 assentos entre 1811 e 1844, dos quais 14 eram de ilegítimos. O capitão Bento Pupo de Gouveia, também natural de Iguape, com 14 escravos em 1801, possuía só uma criança legítima entre as 16 batizadas entre 1812 e 1828 . A lista poderia se prolongar, mas temos já elementos bastantes para tecer algumas conjecturas sobre o quadro delineado.

A primeira ilação: em Iguape, a grande propriedade parece ser condição necessária, porém não suficiente, para garantir a legitimidade das crianças escravas. Vejamos o caso da família Peniche. O número de registros realizados pela viúva e pelo filho de José Antonio Peniche, aliado ao tamanho de sua posse em 1828 (62 cativos), sugere que Antonio José e Ana Maria (os herdeiros) possuíam escravarias relativamente grandes. Tomando por suposto que se tratavam dos dois únicos herdeiros, a partilha provavelmente possibilitou a preservação de boa parte das relações familiares estabelecidas entre os cativos durante as três primeiras décadas do século XIX. No entanto, o envelhecimento dos casais progenitores dos 37 legítimos indicados na tabela 1 e a extinção da prática, promovida pelo Peniche pai, de oficialização das uniões entre os escravos, possivelmente respondem pelo elevado número de crianças naturais associadas aos herdeiros.

Outra inferência: a prosperidade durante a primeira trintena dos Oitocentos, medida tanto pela expansão da atividade rizicultora como pelo 
próprio aumento nas propriedades escravas dos senhores aqui focados, pode ajudar a explicar a maior proporção relativa de legitimidade observada no gráfico 1 naqueles decênios. Todavia, não pode ser considerada forte o bastante para consubstanciar-se em elemento a uniformizar os que aproveitaram aquela, digamos assim, "janela de oportunidade" patrocinada pela gramínea. Conforme veremos com maior detalhe na próxima seção, o perfil demográfico da população cativa iguapense e os indicadores de estrutura de posse evidenciam as disparidades entre o segmento associado ao maior dinamismo econômico e o contingente de proprietários pouco afetado pela "efervescência" gerada pelo arroz, contingente este medido por nossa régua através dos 272 casos (ou 43,9\% dos registros) em que o proprietário apareceu uma única vez nos assentos de batismo entre 1811 e 1850.

Gráfico 2

Intervalo entre o batismo e o nascimento (em dias). Iguape, 1811-1850

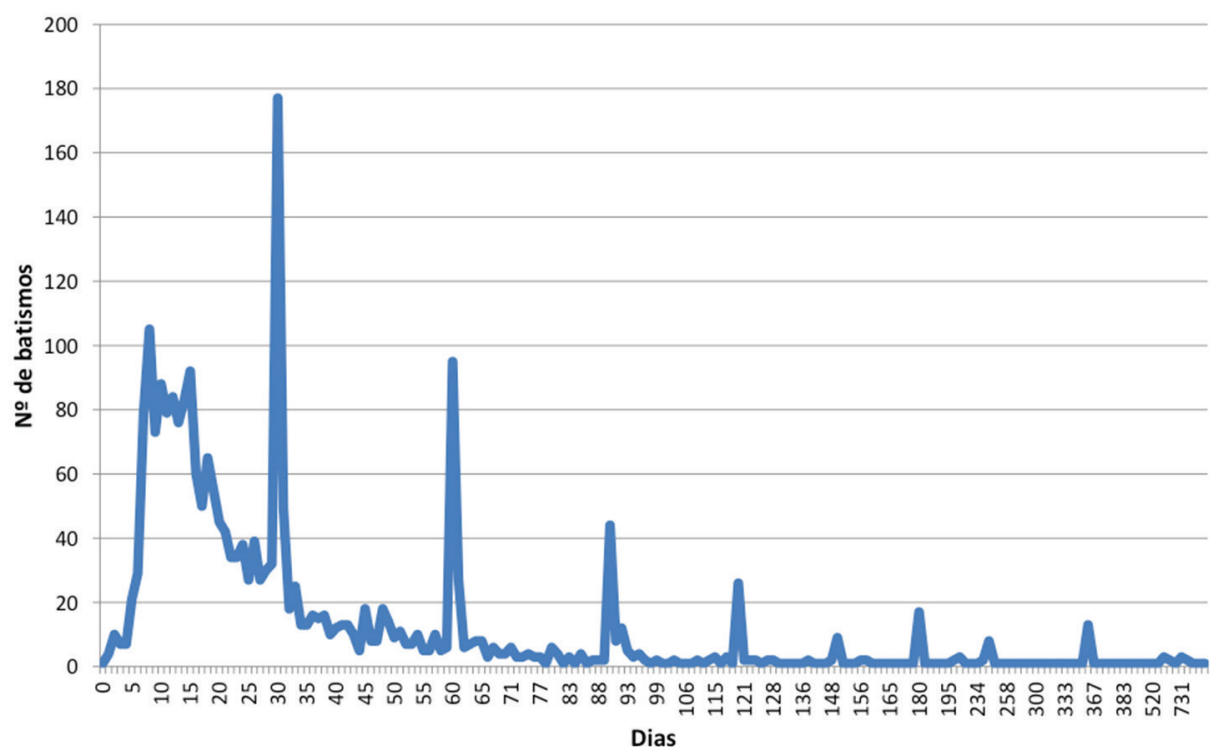

Fonte: Registros de batismos de Iguape.

Uma terceira conjectura acerca do quadro que vimos delineando refere-se à ocorrência de uma mudança expressiva na forma de relacionamento entre escravistas e escravos de Iguape, sugerida pelos dados sobre o intervalo temporal entre o nascimento e o batismo das crianças cativas (gráficos 2 e 3). Examinando os dados fornecidos no gráfico 2, notamos a concentração de batismos até 15 dias após o nascimento (34,2\% dos casos). A porcentagem 
praticamente dobra $(65,1 \%)$ se estendermos o intervalo para 30 dias, momento da primeira concentração nas chamadas "datas redondas".9 O perfil da curva mantém-se semelhante, cada vez com um número menor de casos, após 60, 90, 120, 150, 180, 240 e 365 dias. Adicionalmente, ao observamos os resultados dispostos no gráfico 3, percebemos que o intervalo médio e o mediano apresentaram crescimento ao longo do período, lento até o início da década de 1830 e bem mais intenso na vintena posterior, coincidindo com a redução na participação de legítimos entre as crianças cativas batizadas.

Gráfico 3

Intervalos médio e mediano entre nascimento e batismo. Iguape, 1811-1850

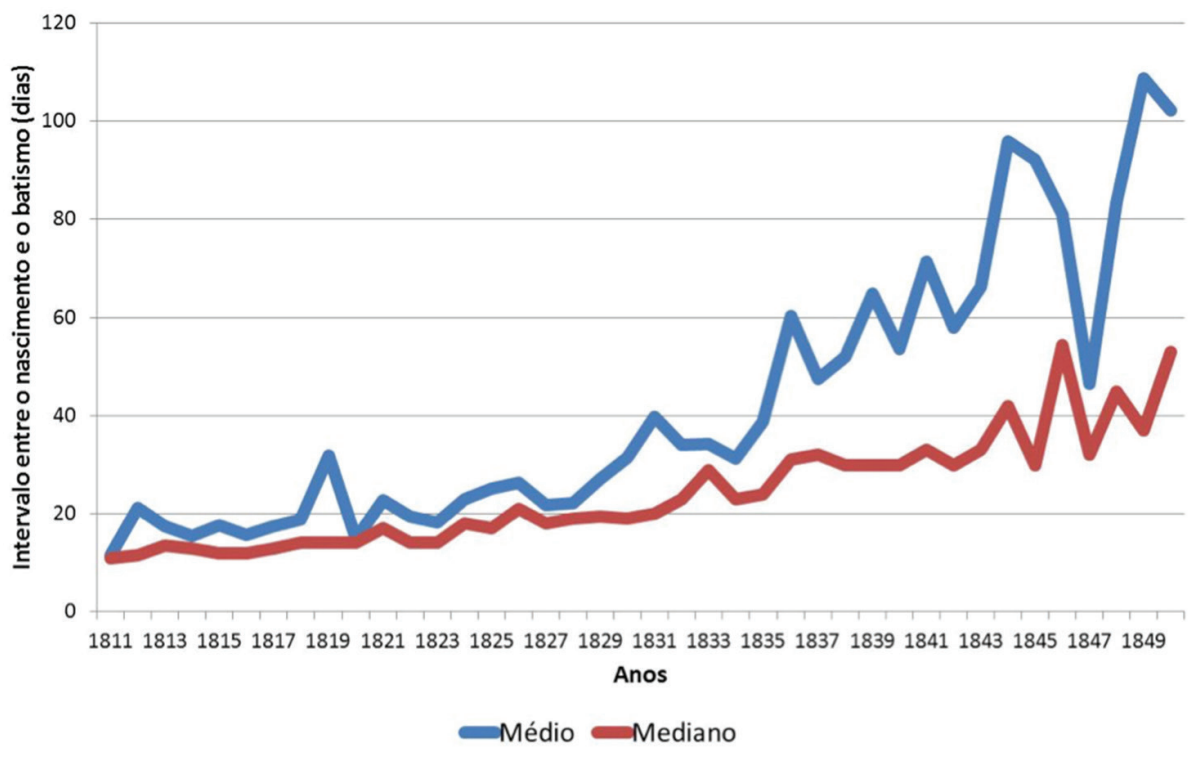

Fonte: Registros de batismos de Iguape.

A mesma tendência foi verificada, por exemplo, em Curitiba durante o século XIX, tanto para livres como para escravos. Os autores do estudo sobre a localidade paranaense sugeriram uma nova conformação de hábitos, que envolvia o batismo doméstico como forma de garantir a salvação da alma do recém-nascido e a realização posterior do rito na igreja, justamente privile-

\footnotetext{
9 Assim entendidos os intervalos em dias correspondentes a múltiplos do mês "redondo" de 30 dias, bem como o intervalo relativo ao ano "redondo" de 365 dias.
} 
giando as "datas redondas". Destacaram, outrossim, que o próprio crescimento da vila colaboraria, aumentando a distância entre o local de nascimento e a igreja, colocando em risco a sobrevivência tanto da mãe quanto da criança. ${ }^{10}$

Destacamos, em outra ocasião, ${ }^{11}$ a ocupação das áreas alagadas ao longo do rio Ribeira e de seus afluentes no contexto da expansão da produção de arroz no Vale do Ribeira. A maior distância a ser vencida certamente concorria para a expansão dos intervalos conforme indica o gráfico 3. Isso certamente motivava o deslocamento do pároco, como de modo inequívoco pudemos perceber durante a década de 1840, quando várias vezes os batismos foram celebrados na capela de Juquiá. E também impelia alguns proprietários a realizar os batismos em outras freguesias, procedimento ao qual voltaremos mais adiante no texto.

\section{Gráfico 4}

Distribuição relativa da quantidade de arroz exportada e batismos mensais. Iguape, 1841-1850

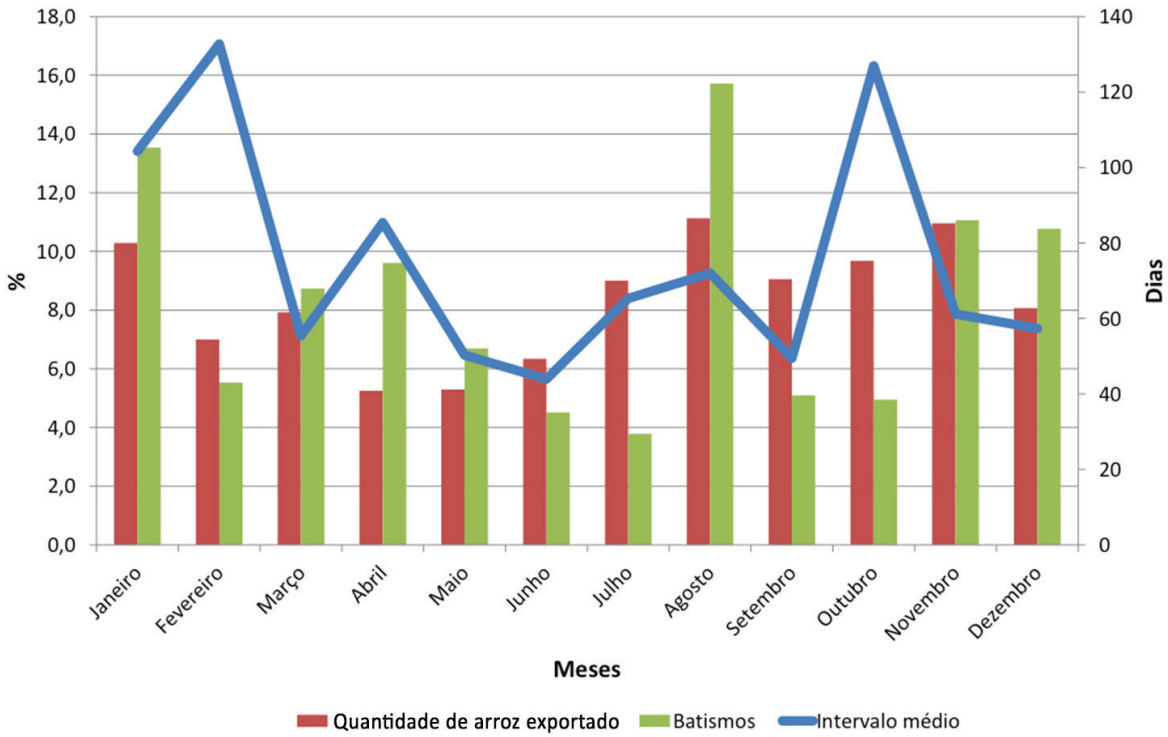

Fontes: Registros de batismo de Iguape e Apesp.

${ }^{10}$ Cf. CARNEIRO, Marina Braga; CHAGAS, Paula Roberta; NADALIN, Sergio Odilon. Nascer e garantir-se no reino de Deus. Curitiba, séculos XVIII e XIX. Revista Brasileira de Estudos Populacionais, v. 27, n. 2, jul./dez. 2010, p. 361-384.

${ }^{11}$ Cf. VALENTIN, Agnaldo. Uma civilização do arroz: agricultura, comércio e subsistência no Vale do Ribeira (1800-1880), cap. 2. Tese de doutorado, História, FFLCH-USP. São Paulo, 2006, p. 76-128. 
Outra influência que merece destaque é o ritmo das atividades econômicas e sociais da localidade. A economia cada vez mais dependente do arroz e um calendário religioso que tem seu auge na festa da padroeira, em agosto, ajudam a compreender parte da sazonalidade observada no intervalo entre o nascimento e o batismo das crianças cativas, conforme é possível visualizar com base nos informes dispostos no gráfico 4 . O resultado para o mês de agosto parece evidente, pois concentra a maior parcela dos batismos computados na década de 1840, além de corresponder a um dos meses com maior quantidade de arroz exportada pelo porto da vila. ${ }^{12}$ Dessa forma, parece claro que o proprietário morador na zona rural, de uma tacada, transportava o arroz colhido, levava sua família para a festa e as crias de suas escravas para o batismo.

Reforça tal quadro a baixa frequência relativa de batismos nos dois meses antecedentes, sugerindo o "adiamento" dos batismos que normalmente ocorreriam nestes meses para o período de festas em louvor ao Bom Jesus. Outros meses, como janeiro e novembro, também indicam a associação entre o transporte de arroz até a região costeira e a maior ocorrência de batismos. Naturalmente, em outros meses, tal vinculação não é percebida, mantendo-se o fluxo de batismos provavelmente oriundo dos escravistas moradores da própria vila ou em áreas mais próximas.

É oportuno elaborarmos, ao término desta seção, um breve sumário dos resultados obtidos até aqui. A tabulação das quantidades de registros de batismos, ano a ano, permitiu-nos perceber a diminuição de ocorrências em torno de 1830, diminuição esta que, sugerimos, poderia estar vinculada às discussões prévias à promulgação da Lei Feijó, em novembro de 1831. Além disso, segmentando os registros pela condição de legitimidade das crianças escravas batizadas, observamos, no decurso do período contemplado, o aumento absoluto e relativo dos casos de crianças ilegítimas, resultado que corrobora achados de vários outros estudiosos do tema da legitimidade dos infantes cativos. No caso de Iguape, é possível que o dinamismo da rizicultura nas três décadas iniciais do século XIX, que coincidem com a parte inicial daquele período, tenha sido um fator que nos ajuda a entender a então maior proporção das crianças legítimas.

Por outro lado, pudemos perceber, também, e reforçamos essa percepção com a apresentação do caso da família Peniche, que a posse de escravarias

\footnotetext{
${ }^{12}$ O período privilegiado no gráfico 4, 1841-1850, relacionou-se à disponibilidade de informações sobre as remessas mensais de arroz via porto de Iguape.
} 
maiores, se necessária, não era, no entanto, suficiente para implicar a legitimidade dos pequenos escravos. Em termos do intervalo entre nascimento e batismo, verificamos que pouco mais de um terço das crianças foi batizado com até 15 dias de idade, proporção que atingiu pouco menos de dois terços se consideramos a faixa etária até 30 dias. O crescimento da localidade decerto colaborou para o movimento ascendente, no tempo, dos valores médios do aludido intervalo. Por fim, a dinâmica da produção e comercialização do arroz, aliada ao calendário religioso no qual se destaca a festa da padroeira no mês de agosto, responderam decerto em grande medida pelas características notadas no tocante à sazonalidade dos assentos paroquiais.

\section{Cruzamento nominativo de fontes}

Nesta seção, confrontamos duas fontes caras aos estudiosos da demografia histórica em território paulista: os recenseamentos populacionais, realizados com maior ou menor regularidade ao longo da segunda metade do século XVIII e da primeira do XIX (também denominados Maços de População, depositados no Arquivo Público do Estado de São Paulo - Apesp), e os registros paroquiais de batismos. Inicialmente, fornecemos um perfil da população escrava presente em Iguape no ano de 1828 segundo os informes contidos no respectivo arrolamento populacional. Em seguida, apresentamos os resultados mediante a realização de um procedimento em dois passos: no primeiro, da lista nominativa para os assentos de batismos, confrontamos cativos com menos de 10 anos e seus proprietários relacionados no documento de 1828 com os assentos presentes no livro de batismos de escravos; o segundo passo, dos assentos paroquiais para a lista nominativa, deriva da extração de um subconjunto comum às duas fontes, isto é, procuramos na lista todos os cativos dos proprietários recenseados, batizados entre 1811 e 1828. Para ambos os casos objetivamos, além do teste de consistência, compreender de forma ampliada a dinâmica reprodutiva revelada parcialmente por cada uma dessas duas fontes.

A lista nominativa dos habitantes de Iguape de 1828 registrou a presença de 249 proprietários e 1.731 escravos, correspondendo à posse média de 6,7 cativos por escravista e um valor mediano igual a 4 , sendo a unidade o valor modal. Pertenciam ao sexo masculino 82,7\% dos senhores e 55,5\% dos 
rev. hist. (São Paulo), n. 171, p. 141-174, jul.-dez., 2014 http://dx.doi.org/10.11606/issn.2316-9141.rh.2014.89010
Agnaldo Valentin e José Flávio Motta

0 primeiro sacramento - batismos de escravos em Iguape (1811-1850)

escravos. Quanto ao estado conjugal dos cativos, casados e viúvos perfaziam $14,9 \%$ da população $(12,8 \%$ dos homens e $17,5 \%$ das mulheres $){ }^{13}$

A distribuição etária dos escravos homens e das escravas pode ser observada, segundo faixas decenais, no gráfico 5. Os dois grupos etários mais jovens distinguiam-se dos demais pelo relativo equilíbrio entre os sexos. Nas faixas etárias de 20 a 49 anos, a predominância masculina vinculava-se decerto à opção de compra preferencial e, também, em alguma medida, à provável concentração da morte materna entre as mulheres no aludido segmento etário. ${ }^{14}$ A partir dessa distribuição por idades, calculamos a relação entre crianças escravas de 0 a 9 anos e mulheres cativas de 15 a 49 anos, igual a 894 crianças para 1.000 mulheres (ou 449, se computadas crianças de 0 a 4 e mulheres de 15 a 44 anos). ${ }^{15}$

${ }^{13}$ Francisco Vidal Luna, estudando 25 localidades paulistas (entre elas a vila de Iguape em 1828), verificou que 80,0\% dos proprietários de escravos no ano de 1829 (ou 1828 em alguns casos, ou ainda 1830 em Cunha) pertenciam ao sexo masculino. A posse média (escravistas homens e mulheres), igual a 7,25 cativos por proprietário para o conjunto das localidades, oscilou entre 4,64 (Caminho do Sul) a 11,27 (Oeste Paulista); o valor mediano esteve entre 3 e 4. cf. LUNA, Francisco Vidal et al. Escravismo em São Paulo e Minas Gerais. São Paulo: Edusp; Imprensa Oficial do Estado de São Paulo, 2009, p. 349 e 387. Quanto à distribuição dos escravos segundo o gênero, calculamos uma razão de sexo de 124,5 homens para 100 mulheres na Iguape de 1828, magnitude inferior à observada por Luna (158,7) para o conjunto das 25 localidades. Cf. Idem, p. 115.

${ }^{14}$ Temos em mente o moderno conceito adotado, por exemplo, pelo Ministério da Saúde: “Morte materna é a morte de uma mulher durante a gestação ou até 42 dias após o término da gestação, independentemente da duração ou da localização da gravidez" (BRASIL. Ministério da Saúde. Secretaria de Atenção à Saúde. Departamento de Ações Programáticas Estratégicas. Manual dos comitês de mortalidade materna. $3^{\text {a }}$ ed. Brasília: Editora do Ministério da Saúde, 2007, p. 12-13).

15 Tomando uma vez mais como referencial para comparação o conjunto de 25 localidades referido na nota 12, verificamos que os resultados fornecidos por Luna mostraram-se algo inferiores aos nossos: respectivamente, 717,8 e 364,7. Cf. LUNA, Francisco Vidal et al. Escravismo em São Paulo e Minas Gerais. São Paulo: Edusp; Imprensa Oficial do Estado de São Paulo, 2009, p. 118. A participação de crianças de 0 a 4 anos em Iguape era de 11,2\% dos escravos (ou 23,0\%, se considerado o grupo de 0 a 9 anos); esses dois porcentuais superaram as cifras correlatas calculadas por Luna, as quais se igualaram, respectivamente, a 8\% e 16\%. Cf. Idem, p. 99. 
Gráfico 5

Distribuição da população escrava segundo sexo e faixas etárias decenais. Iguape, 1828

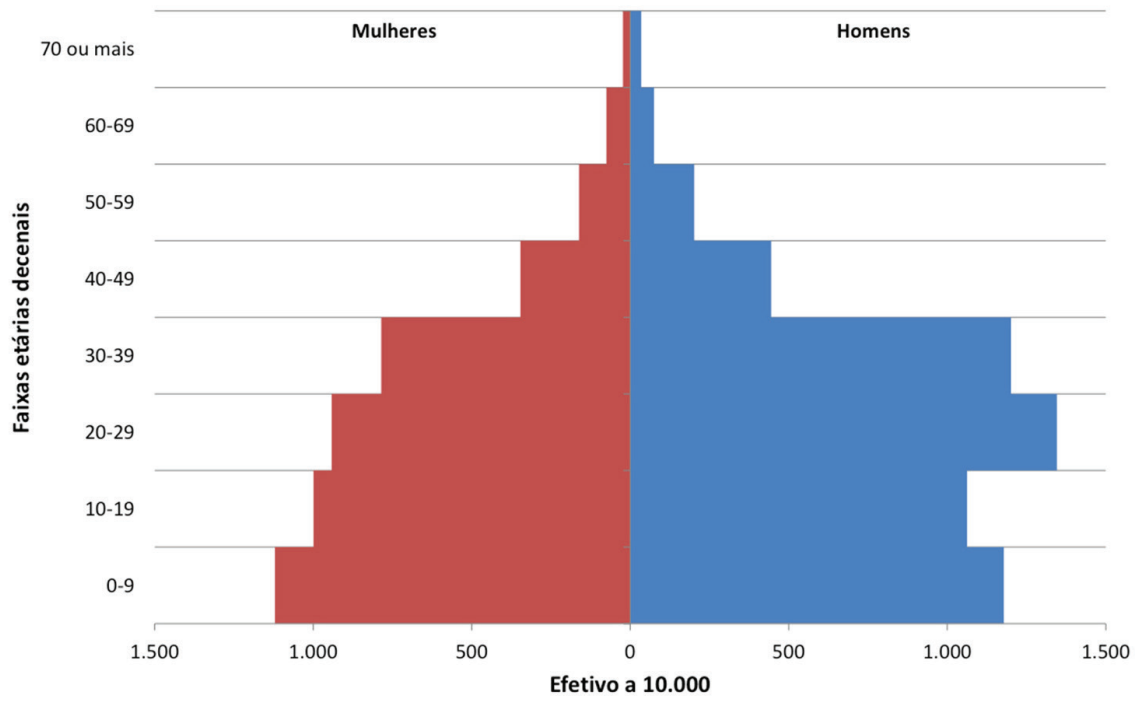

Fonte: Apesp.

Na tabela 2, apresentamos os escravistas e seus cativos distribuídos segundo faixas de tamanho das posses, destacando em separado os escravos com 15 ou menos anos de idade, os quais nos remetem aos casos de crianças batizadas a partir de 1811. Além da distribuição que concentra os cativos nas maiores posses pertencentes a um pequeno número de escravistas, notamos que essas propriedades também agregavam a maior parte dos escravos com 15 anos ou menos. No entanto, salientemos que esse grupo etário compunha parcelas que oscilavam entre $30 \%$ a $38 \%$ do total de pessoas em todos os segmentos de tamanho das escravarias. ${ }^{16}$

${ }^{16}$ Não verificamos diferença estatística significativa na idade média dos escravos com 15 anos ou menos entre as diferentes faixas de posse $(p=0,13)$. Segundo anotações sobre a origem desses escravos, 83,5\% nasceram em Iguape contra 13,1\% oriundos da África. De outra parte, recorrendo novamente ao repertório apresentado por Vidal Luna, e considerando a distribuição de crianças de 0 a 9 anos por distintas faixas de posse, notamos que em Iguape havia maior participação de crianças no conjunto dos escravos possuídos: 16,5\% em Iguape vis-à-vis 15,3\% nas 25 localidades paulistas, nas escravarias compostas por até cinco pessoas; 24,7\% contra 20,2\% no grupo de 6 a 10 escravos; 28,8\% versus 17,5\% nas posses com 11 a 20 cativos e 28,3\% contra 14,8\% nas escravarias de 21 a 40 escravos. A exceção radicou na mais elevada faixa de tamanho, de 41 cativos ou mais, com 12,9\% (Iguape) e 13,1\% (25 localidades; cf. Idem, p. 123). Dessa breve apresentação dos resultados, podemos destacar que, embora Iguape estivesse 
Tabela 2

Distribuição de proprietários e escravos segundo faixas de tamanho das posses (FTP). Iguape, 1828

\begin{tabular}{|c|c|c|c|c|c|c|}
\hline \multirow{2}{*}{ FTP } & \multicolumn{2}{|c|}{ Proprietários } & \multicolumn{2}{c|}{ Escravos } & \multicolumn{2}{c|}{$\begin{array}{c}\text { Escravos de 0 a } \\
15 \text { anos }\end{array}$} \\
\cline { 2 - 7 } & $\mathbf{N}$ & $\mathbf{0}$ & $\mathbf{N}$ & $\mathbf{0}$ & $\mathbf{N}$ & $\mathbf{0}$ \\
\hline 1 a 4 & 139 & 55,9 & 299 & 17,3 & 91 & 14,6 \\
\hline 5 a 9 & 63 & 25,3 & 400 & 23,1 & 146 & 23,4 \\
\hline 10 a 19 & 28 & 11,2 & 393 & 22,7 & 151 & 25,8 \\
\hline 20 ou mais & 19 & 7,6 & 639 & 36,9 & 226 & 36,2 \\
\hline Total & $\mathbf{2 4 9}$ & $\mathbf{1 0 0 , 0}$ & $\mathbf{1 . 7 3 1}$ & $\mathbf{1 0 0 , 0}$ & $\mathbf{6 2 4}$ & $\mathbf{1 0 0 , 0}$ \\
\hline
\end{tabular}

Fonte: Apesp.

Nossa primeira aproximação ao confronto entre os dados constantes no livro de batismos e os colhidos na lista de habitantes de 1828 centra-se nas informações daqueles proprietários presentes no arrolamento nominativo cujas posses continham crianças escravas com menos de 10 anos. Identificamos na lista 142 proprietários e 442 crianças nessa faixa etária, sendo 229 meninos e 213 meninas. E localizamos os assentos de batismos de 238 (ou 53,9\%) desses pequenos cativos. Esse primeiro resultado bruto pode ser objeto de qualificação segundo outros recortes conforme procedemos a seguir.

De início, destacamos 28 escravistas ausentes nos registros de batismo, possuidores de 46 crianças escravas. ${ }^{17}$ Classificamos os 114 proprietários res-

imersa na fase de maior dinamismo gerado pela expansão do cultivo de arroz, guardava traços híbridos na composição de sua população escrava. Isso porque raramente se aproxima das regiões mais dinâmicas de São Paulo (Oeste Paulista e Vale do Paraíba); porém se mantém distanciada também do conjunto das regiões com desenvolvimento mais contido. Tal contexto fica evidente, por um lado, na maior participação masculina no grupo etário de 20 a 39 anos, aqui tomado como um indicador da capacidade de compra de cativos africanos. Por outro, nos sinais claros de expansão da população através da reprodução natural, como sugere o peso das crianças no contingente cativo. Tal consideração, por fim, deve ser entendida à luz da interpretação de Motta sobre a manutenção da família escrava mesmo em um contexto de maior dinamismo, a exemplo do verificado na localidade paulista de Bananal entre 1801 e 1829. Cf. MOTTA, José Flávio. Corpos escravos, vontades livres: posse de escravos e família escrava em Bananal (1801-1829). São Paulo: Fapesp, Annablume, 1999.

17 Tais escravistas possuíam oito escravos em média, com mediana e moda iguais a seis. Ademais, em 16 casos, não havia mais do que uma criança escrava com menos de 10 anos de idade. Dentre esses 28 proprietários, destacamos o caso de Joaquim Rodrigues da Silva, com 32 anos em 1828, que 
tantes e as 396 crianças por eles possuídas em três grupos. Dessa forma, 211 crianças também estavam presentes nos registros de batismo associados diretamente ao proprietário presente na lista de 1828. Outras 27 foram localizadas através de vínculos com escravistas que detinham ligações familiares com os arrolados no referido ano. ${ }^{18}$ Não encontramos os registros de batismo das demais 158 crianças. A tabela 3 apresenta a distribuição dos 442 escravos com menos de 10 anos segundo faixas de tamanho de posse e de acordo com os três grupos descritos. ${ }^{19}$

\section{Tabela 3}

Distribuição dos escravos com menos de 10 anos de idade, presentes em 1828, por faixa de tamanho de posse (FTP) e segundo presença no livro de batismos. Iguape, 1811 a 1828

\begin{tabular}{|c|c|c|c|c|}
\hline \multirow{2}{*}{ FTP } & \multirow{2}{*}{$\begin{array}{c}\text { Total de } \\
\text { crianças }\end{array}$} & Sim & Não & $\begin{array}{c}\text { Proprietário não } \\
\text { localizado }\end{array}$ \\
\cline { 3 - 5 } & 54 & 24 & 17 & 13 \\
\hline 1 a 4 & 105 & 54 & 24 & 27 \\
\hline 5 a 9 & 124 & 70 & 54 & 0 \\
\hline 10 a 19 & 159 & 90 & 63 & 6 \\
\hline 20 ou mais & $\mathbf{4 4 2}$ & $\mathbf{2 3 8}$ & $\mathbf{1 5 8}$ & $\mathbf{4 6}$ \\
\hline Total & &
\end{tabular}

Fontes: Apesp e Livro de registro de batismos de Iguape.

O resultado reafirma o padrão de concentração de crianças nas propriedades com maior número de escravos (64,0\% das crianças presentes nas posses com 10 ou mais pessoas). No que respeita à segmentação a partir do cruzamento com os assentos paroquiais, observamos, nas escravarias me-

possuía seis crianças escravas em sua posse formada por 27 pessoas. Trata-se, provavelmente, de um morador com pouco tempo de residência em Iguape e com as crianças batizadas em outro local.

${ }^{18}$ Utilizamos a lista nominativa de 1815 como referência para a confirmação das relações de parentesco.

${ }^{19}$ Neste primeiro passo do cruzamento nominativo realizado, em que partimos do recenseamento de 1828 e o confrontamos com os assentos paroquiais, optamos por referir a legitimidade ou ilegitimidade das crianças escravas apenas no estudo de caso contemplado adiante no texto, qual seja, a escravaria de Vitorino José Lopes. Maior atenção a esse tema será dada no segundo e último passo do aludido cruzamento, no qual partimos dos registros de batismos e com o qual encerramos esta seção do artigo. 
nores (até nove cativos), constarem no livro de batismos 65,5\% das crianças, contra 57,8\% nas maiores posses.

Uma análise minuciosa dos escravistas e das crianças, com batismo localizado ou não, permite outras considerações pertinentes. Dos 42 escravistas com todas as crianças também presentes no livro de batismos, 22 possuíam apenas um cativo com menos de 10 anos e praticamente todos detinham posses reduzidas, de 1 a 7 escravos. ${ }^{20} \mathrm{O}$ número de crianças batizadas relaciona-se positivamente, grosso modo, com o tamanho da posse de cativos; assim, por exemplo, o escravista Antonio Pinto de Almeida aparece com todas as suas sete crianças batizadas e integrando sua escravaria formada por 17 indivíduos. Nesse conjunto de 42 senhores é notável o caso de Antonio Borges Diniz, detentor de 51 escravos na lista de 1828, sendo apenas quatro com menos de 10 anos de idade, todos batizados. ${ }^{21}$

No outro extremo, estão os 23 proprietários de 42 crianças com assentos de batismo não localizados. Apenas oito desses 23 senhores apareceram nos assentos de batismo antes de 1828, sugerindo que a maior parte dos casos seria composta por proprietários novos e as crianças presentes na lista nominativa seriam aquisições realizadas em momentos mais próximos a 1828, ou teriam sido batizadas pelo proprietário anterior (se originárias de doações ou heranças). Também não é possível descartar a possibilidade de o batismo haver ocorrido em outra paróquia, como sucedeu com Joaquim Pereira de Oliveira, originário de Xiririca e morador em Juquiá no ano de 1828. Das oito crianças presentes entre seus 14 escravos, pelo menos quatro foram batizadas na sua paróquia de nascimento.

O grupo mais numeroso corresponde aos 49 escravistas detentores de crianças com menos de dez anos com presença parcial nas duas fontes. Eram 271 tais crianças, 30,6\% dos 885 escravos possuídos por aqueles 49 senhores e indicados na lista de 1828, sendo localizados os assentos de batismo de 155 delas (57,2\%). Trata-se de um conjunto heterogêneo, tanto no número de crianças indicadas como na participação de batizados identificados em Iguape. Selecionamos um caso dessa meia centena de proprietários para análise mais minuciosa: o do açoriano Vitorino José Lopes, senhor de 33 escravos

\footnotetext{
${ }^{20}$ A exceção é Antonio Neves Pinheiro Vidal, cuja escravaria somava 12 pessoas, sendo apenas uma com menos de 10 anos.

${ }^{21}$ Conforme veremos adiante no texto, esse escravista esteve associado, entre 1818 e 1828, a 17 batismos de crianças cativas.
} 
em 1828, dos quais 16 menores de 10 anos. ${ }^{22}$ Entre 1813 e 1828, foram batizadas 24 crianças pertencentes a Vitorino, oriundas de sete núcleos familiares. O quadro 1 confronta informes extraídos dos assentos de batismo daquelas 16 crianças (e seus pais) com dados colhidos na lista nominativa de 1828.

\section{Quadro 1}

Crianças (com menos de 10 anos e presentes da lista nominativa de 1828) e mães escravas pertencentes a Vitorino José Lopes

\begin{tabular}{|c|c|c|c|c|c|c|}
\hline $\begin{array}{l}\text { Nome da } \\
\text { criança }\end{array}$ & $\begin{array}{c}\text { Idade na } \\
\text { lista }\end{array}$ & Nascimento & $\begin{array}{c}\text { Idade em } \\
31 / 12 / 1828\end{array}$ & Mãe & Legitimidade & $\begin{array}{l}\text { Idade da } \\
\text { mãe na lista }\end{array}$ \\
\hline Germano & 7 & - & - & - & - & - \\
\hline Benedita & 10 & - & - & - & - & - \\
\hline Máximo & 4 & - & - & - & - & - \\
\hline Tereza & 8 & - & - & - & - & - \\
\hline Floriana & 7 & 03/06/1826 & 2 & Ana & Legítimo & 51 \\
\hline Francisco & 8 & $06 / 06 / 1824$ & 4 & Ana & Legítimo & 51 \\
\hline Bento & 8 & 20/03/1825 & 3 & Antonia & Natural & 24 \\
\hline Tereza & 6 & $05 / 02 / 1827$ & 1 & Vitoriana & Natural & 30 \\
\hline Josefa & 8 & 14/09/1819 & 9 & Antonia & Legítimo & 24 \\
\hline Ricardo & 8 & 18/11/1821 & 7 & Antonia & Legítimo & 24 \\
\hline Custódio & 7 & 08/11/1821 & 7 & Isabel & Legítimo & 25 \\
\hline Inácio & 7 & $16 / 12 / 1819$ & 9 & Isabel & Legítimo & 25 \\
\hline Mariana & 7 & $24 / 10 / 1823$ & 5 & Isabel & Legítimo & 25 \\
\hline Candido & 7 & 08/09/1818 & 10 & Vitoriana & Natural & 30 \\
\hline Moises & 7 & $12 / 09 / 1822$ & 5 & Vitoriana & Natural & 30 \\
\hline Prudente & 8 & 18/12/1819 & 9 & Vitoriana & Natural & 30 \\
\hline
\end{tabular}

Fontes: Apesp e Livro de registro de batismos de Iguape.

${ }^{22}$ Sobre a inserção do rizicultor Vitorino José Lopes na sociedade e economia de Iguape, ver VALENTIN, Agnaldo. Uma civilização do arroz: agricultura, comércio e subsistência no Vale do Ribeira (1800-1880). Tese de doutorado, História, FFLCH-USP. São Paulo, 2006, p. 265-275. 
Além das quatro primeiras crianças não localizadas nos registros de batismos, ${ }^{23}$ a elevada diferença de idade nos quatro cativos seguintes não autoriza seus cômputos nas equivalências entre as duas fontes. Assim, contabilizamos apenas oito crianças com batismo na posse de Vitorino José Lopes, representando 50\% dos escravos com menos de 10 anos que ele detinha em 1828. Das mães indicadas contamos outras cinco crianças nascidas entre 1819 e 1828 que não constavam na lista nominativa, cujo destino podemos apenas conjecturar (eventual venda, doação etc.; e, com maior probabilidade, a morte). Sobre a legitimidade das crianças, apenas a escrava Ana aparece com a indicação de casada no rol de moradores de Iguape, não obstante Isabel e Antonia constarem nos assentos paroquiais como casadas com os escravos Joaquim e Francisco, respectivamente.

O estudo do caso de Vitorino José Lopes auxilia-nos a compreender o universo das relações escravas em Iguape. E isso tanto por sua presença como proprietário de escravos batizados em boa parte do período levantado (1813 a 1841), como pelo número total de crianças "suas" batizadas (45 casos), o que o posicionou como o sexto mais frequente entre os escravistas compulsados. De início, ressalvemos que o recorte apresentado no quadro 1 quanto à condição de legitimidade, com maior frequência de legítimos, não corresponde ao observado para a totalidade dos informes acerca desse escravista colhidos nos assentos paroquiais $(64,4 \%$ de crianças naturais do total de 45 pequenos cativos batizados pelo açoriano). Identificamos pelo menos 13 mães distintas, o que implica a média de 3,1 filhos por mãe, ${ }^{24}$ porém com oscilações expressivas: Vitoriana, entre 1818 e 1836, teve oito filhos batizados; o casal Isabel e Joaquim, sete, e a dupla Ana e João, seis. Na outra ponta figuraram Josefa, Feliciana, Rita e Ana, com apenas um filho batizado. Para aquelas com maior número de filhos, o intervalo entre nascimentos oscilou de 1,7 a 2,3 anos, exceto para Antonia (intervalo de 5,5 anos).

No que respeita aos padrinhos de batismo das crianças, notamos que cinco dos seis filhos gerados pelo casal Ana e João foram batizados pelos mesmos escravos, Joaquim e Clara, pertencentes inicialmente ao pároco Diogo Rodrigues Cunha e depois à sua sobrinha, Ana Clara da Silva (possivelmente Joaquim foi alforriado na transição, pois passou a ser registrado como

\footnotetext{
${ }^{23}$ Optamos por rejeitar a possibilidade de eventuais trocas de nomes entre as duas fontes, a exemplo da alteração entre "Germano" (lista de 1828) e "Generoso" (registro de batismo), ambos com sete anos.

${ }^{24}$ Em um dos casos não havia a identificação da mãe.
} 
rev. hist. (São Paulo), n. 171, p. 141-174, jul.-dez., 2014 http://dx.doi.org/10.11606/issn.2316-9141.rh.2014.89010
Agnaldo Valentin e José Flávio Motta

0 primeiro sacramento - batismos de escravos em lguape (1811-1850)

Joaquim Manoel). ${ }^{25} \mathrm{O}$ último dos filhos de Ana e João teve ainda Clara como madrinha, mas o padrinho foi o escravo Bruno, filho de Clara. Joaquim Manoel também batizou um dos filhos de Vitoriana, porém a madrinha foi Jacinta, pertencente à sogra de Vitorino José Lopes. Os demais rebentos de Vitoriana ou foram apadrinhados por escravos de Antonio Borges Dinis ou por supostos livres. Por seu turno, os sete filhos do casal Isabel e Joaquim possuíram apenas três padrinhos diferentes, os três escravos e pertencentes a distintos senhores (dois destes aparentados com a esposa de Vitorino), e quatro madrinhas cativas pertencentes também a proprietários diversos (três dos quais igualmente parentes da esposa de Vitorino). Importa ressaltar que nenhum dos padrinhos escravos pertencia à mesma escravaria das crianças batizadas. ${ }^{26}$ Já os três filhos de Luisa tiveram como padrinhos pessoas livres, assim como o único filho de Delfina, todos nascidos entre 1834 e 1841.

Em suma, no que respeita ao primeiro dos passos do cruzamento nominativo envolvendo assentos paroquiais e a lista nominativa de 1828, descrito na abertura desta seção, cabe salientar de início a elevada proporção (mais da metade) de crianças escravas com menos de dez anos presentes no recenseamento cujos registros de batismo localizamos. Ademais, se as crianças nessa faixa etária concentravam-se fortemente $(64,0 \%)$ nas maiores escravarias (10 ou mais cativos), foi nas posses menores (com até nove integrantes), que obtivemos um mais elevado porcentual de identificação desses pequenos escravos nos livros batismais (65,5\% versus 57,8\% nas escravarias maiores). De outra parte, para mais de quatro dezenas de escravistas detentores de crianças com nove ou menos anos, encontramos o assento de batismo de todas elas. Os casos em que nenhum registro batismal foi encontrado corresponderam a um total de 23 proprietários. As situações mais frequentes foram aquelas de possuidores de crianças cativas das quais apenas para algumas localizamos os assentos de batizados. E estudamos com mais detalhe um desses casos mais frequentes, do açoriano Vitorino José Lopes, a partir do qual avançamos algumas observações acerca do compadrio; sobretudo, notamos a relevância dos padrinhos e madrinhas escravos, tal como seus afilhados,

${ }^{25}$ Vale observar que estamos cientes do valor meramente ilustrativo das observações sobre o compadrio constantes deste parágrafo. Afinal, tais observações são feitas a partir tão-somente do caso de Vitorino José Lopes. Não obstante, entendemos que esse valor ilustrativo justifica a inclusão no texto das aludidas observações.

${ }^{26}$ No subperíodo entre 1811 e 1828 verificamos que apenas 66 crianças batizadas possuíam padrinhos e madrinhas escravos integrantes da mesma escravaria, representando 13,1\% dos 503 casos onde pelo menos um dos padrinhos possuía tal condição social. 
sendo que nenhum desses padrinhos e madrinhas era propriedade de Vitorino, embora alguns pertencessem a escravistas aparentados do açoriano.

Cabe agora apresentarmos os resultados do segundo dos passos do procedimento por nós contemplado. Desta feita, o cruzamento entre fontes, registros de batismo e lista nominativa, considerando o universo de crianças escravas batizadas entre 1811 e 1828, envolveu, além da identificação nominativa dos escravistas no recenseamento de 1828, a recuperação de informações em casos nos quais essa identificação foi impossível, pela ausência do proprietário registrado no livro paroquial. Essa recuperação foi feita, em especial, através de seus herdeiros presentes na lista, amiúde a viúva ou seus filhos. Tal segmento correspondeu a 28 escravistas dos 220 presentes no livro de batismos até 1828 e responsáveis por 165 dos 990 assentos. Não obstante, deixamos de localizar 93 proprietários, associados a 262 batismos, e tampouco identificamos seus eventuais herdeiros, na lista de $1828 .{ }^{27}$ Dessa forma, o conjunto privilegiado por nossa análise no bojo desse segundo exercício abrangeu 127 proprietários e 728 crianças batizadas.

No confronto entre as duas fontes, localizamos 305 escravos batizados e recenseados na lista nominativa de 1828, o que corresponde a 30,8\% dos escravos com registro de batismo entre 1811 e 1828 e a 49,3\% dos cativos com idades entre 0 e 15 anos presentes em 1828. Examinemos como se dava a distribuição destes escravos na estrutura escravocrata de Iguape. Em relação à composição por sexo, verificamos um equilíbrio tanto entre as crianças localizadas como entre as ausentes da lista de 1828 (51,8\% e 50,8\% de meninos, respectivamente). O gráfico 6 traz o número de crianças batizadas pertencentes aos proprietários identificados ou com informes recuperados na lista de 1828, bem como o total de batismos realizados nos respectivos anos. Por mera conveniência com o intuito de facilitar a redação, tanto no gráfico 6 , como daqui para a frente no texto, denominaremos o conjunto (escravistas identificados na lista de 1828 + os 28 casos cujas informações foram recuperadas nos domicílios recenseados de herdeiros dos proprietários constantes dos assentos paroquiais) como "proprietários presentes na lista de 1828".

\footnotetext{
${ }^{27}$ Alguns claramente não habitavam a vila de Iguape, como Catarina Eufrásia, que promoveu o batismo de 10 crianças cativas na matriz iguapense; segundo o inventário de bens rústicos de 1818, ela possuía duas sortes de terras na Jureia, porém residia em Conceição de Itanhaém. Assim também João Antonio da Costa Mendonça, que batizou 24 crianças entre 1812 e 1835. Através de um dos assentos verificamos ser João morador de Cananeia; sobre ele tínhamos referência apenas na lista de 1801, quando ainda morava em Iguape.
} 
Verificamos que tais escravistas eram responsáveis por quatro em cada cinco batismos $(81,6 \%)$ ocorridos nos três últimos anos do lapso em tela (1826, 1827 e 1828). A participação tendeu a declinar à medida que recuamos no tempo até o início do período: entre 1818 e 1825 oscilou em torno de 74,8\%, e de 68,8\% nos primeiros sete anos considerados (1811 a 1817). Os resultados devem ser interpretados não apenas em função de eventuais emigrações de iguapenses ou da presença de não iguapenses batizando seus cativos na paróquia, como também da própria possibilidade de morte dos escravistas. E isto em que pese nosso esforço já mencionado com vistas à recuperação de informações, através da localização de eventuais herdeiros, no cotejo entre os dois diferentes tipos de fontes primárias compulsadas. Ademais, com o número de batismos superando os 50 casos por ano a partir de 1817, o que refletiu o próprio crescimento da população escrava na região, o universo de proprietários ampliou-se, favorecendo sua identificação no rol de moradores.

\section{Gráfico 6}

Distribuição absoluta do total de crianças cativas batizadas e daquelas com os respectivos proprietários presentes na lista nominativa de 1828. Iguape, 1811 a 1828

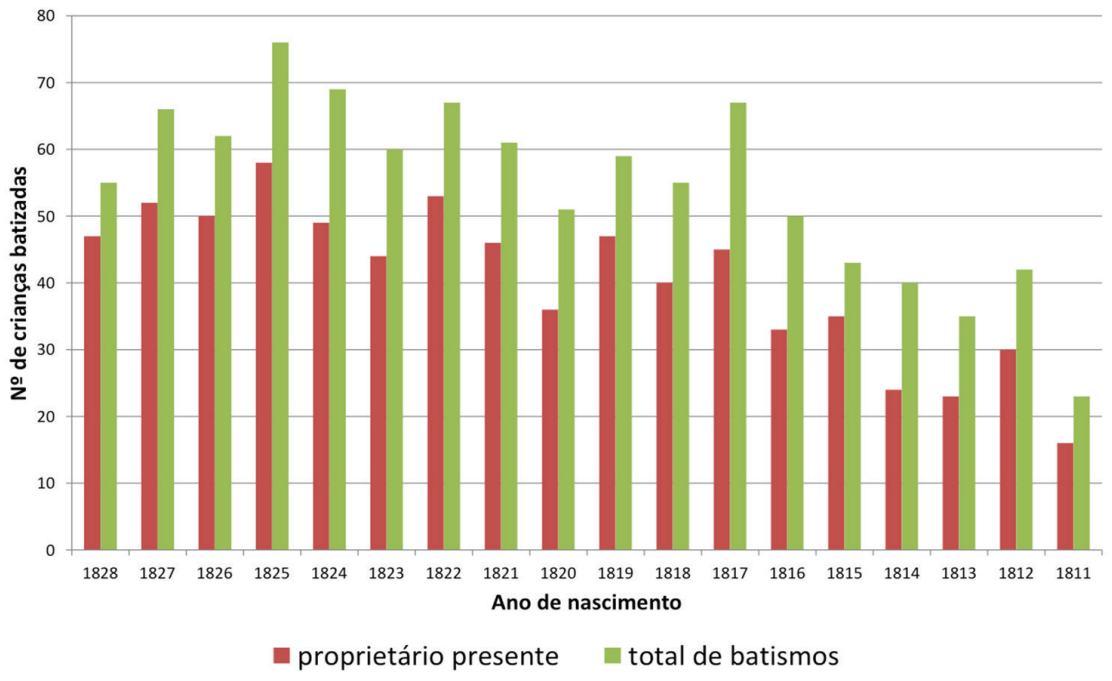

Fontes: Apesp e Livro de registro de batismos de Iguape.

O maior sucesso de nossos esforços de identificação, na lista nominativa de 1828, das crianças cativas batizadas no período de 1811 a 1828, para os casos objeto dos assentos paroquiais realizados nos anos mais próximos ao arrolamento censitário, é também evidenciado pela observação do gráfico 
rev. hist. (São Paulo), n. 171, p. 141-174, jul.-dez., 2014 http://dx.doi.org/10.11606/issn.2316-9141.rh.2014.89010
Agnaldo Valentin e José Flávio Motta

0 primeiro sacramento - batismos de escravos em Iguape (1811-1850)

7. Nele fornecemos a distribuição das ditas crianças de acordo com a sua localização ou não na lista, crianças estas pertencentes aos proprietários presentes no ano de 1828 e tomadas segundo o ano de nascimento. ${ }^{28}$ Com oscilações localizamos, em média, 49,7\% das crianças nascidas entre 1822 e 1828. ${ }^{29}$ No período entre 1816 e 1821, a frequência reduziu-se a 36,3\% e, no quadriênio 1811-1814, a 27,3\%. ${ }^{30}$ Esses resultados revelam, a priori, a combinação dos fatores mortalidade, transações e doações, responsáveis pelo desaparecimento das crianças nascidas nos anos da década de 1810, sem esquecer a possibilidade de ocorrência de manumissões.

\section{Gráfico 7}

Distribuição das crianças cativas batizadas, segundo ano de nascimento e de acordo com sua identificação (sim ou não) na lista nominativa de 1828. Iguape, 1811 a 1828

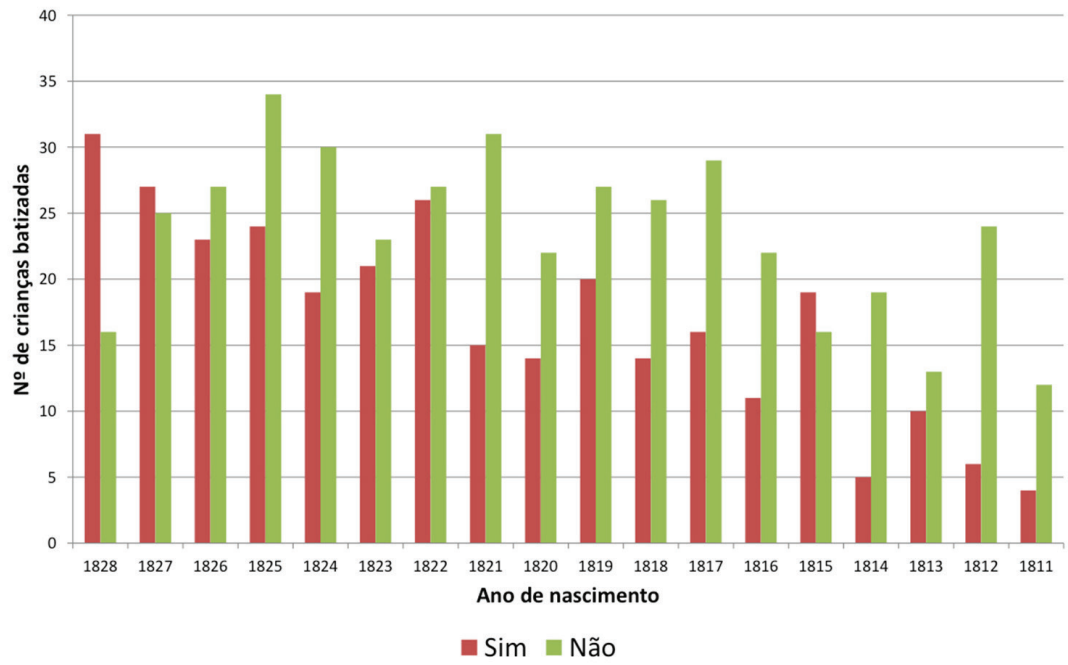

Fontes: Apesp e Livro de registro de batismos de Iguape.

\footnotetext{
${ }^{28}$ Trabalhamoscom 721 casos, uma vezqueseteregistrosnãoinformavam a data denascimento da criança.

${ }^{29}$ Tais valores aproximam-se das taxas de mortalidade calculadas por Maria Luíza Marcílio para a cidade do Rio de Janeiro na década de 1870: “Ora, se de 40\% a 60\% das crianças que nasciam morriam até os 12 meses, e se 60\% e mais delas não ultrapassavam a faixa etária de cinco anos podemos, por aí só, aferir sobre as terríveis condições socioeconômicas e sanitárias da população carioca". MARCíLIO, Maria Luiza. Mortalidade e morbidade da cidade do Rio de Janeiro imperial. Revista de História, nº 127-128, ago-dez/1992 a jan-jun/1993, p. 59. A autora considerou a população em geral; seria plausível, pois, imaginar uma sobrevida menor para os infantes escravos.

${ }^{30}$ Excluímos o ano de 1815 pela evidente atipicidade.
} 


\section{Tabela 4}

Distribuição das crianças cativas batizadas e localizadas na lista de 1828 segundo diversos atributos dos proprietários. Iguape, 1811 a 1828

\begin{tabular}{|c|c|c|c|c|c|c|}
\hline \multirow{2}{*}{$\begin{array}{l}\text { Atributos dos } \\
\text { proprietários }\end{array}$} & \multirow{2}{*}{$\begin{array}{c}\text { Total de } \\
\text { batismos } \\
(2) \\
\end{array}$} & \multicolumn{2}{|c|}{ Criança na lista } & \multirow{2}{*}{$\begin{array}{l}\% \text { no } \\
\text { total }\end{array}$} & \multirow{2}{*}{$\begin{array}{c}\% \text { nas } \\
\text { localizadas }\end{array}$} & \multirow{2}{*}{$\begin{array}{l}\text { Permanência } \\
(1) /(2) \times 100\end{array}$} \\
\hline & & Sim (1) & Não & & & \\
\hline \multicolumn{7}{|l|}{ Sexo } \\
\hline Masculino & 677 & 276 & 401 & 93,0 & 90,5 & 40,8 \\
\hline Feminino & 51 & 29 & 22 & 7,0 & 9,5 & 56,9 \\
\hline Total & 728 & 305 & 423 & 100,0 & 100,0 & 41,9 \\
\hline \multicolumn{7}{|l|}{ FTP } \\
\hline $1 \mathrm{a} 4$ & 70 & 20 & 50 & 9,6 & 6,6 & 28,6 \\
\hline 5 a 9 & 165 & 71 & 94 & 22,7 & 23,3 & 43,0 \\
\hline 10 a 19 & 179 & 88 & 91 & 24,6 & 28,9 & 49,2 \\
\hline 20 ou mais & 313 & 126 & 187 & 43,1 & 41,3 & 40,3 \\
\hline Total $^{*}$ & 727 & 305 & 422 & 100,0 & 100,0 & 42,0 \\
\hline \multicolumn{7}{|c|}{ Condição conjugal } \\
\hline Solteiros & 106 & 47 & 59 & 15,4 & 14,6 & 44,3 \\
\hline Casados & 480 & 198 & 282 & 64,9 & 65,9 & 41,3 \\
\hline Viúvos & 142 & 60 & 82 & 19,7 & 19,5 & 42,3 \\
\hline Total & 728 & 305 & 423 & 100,0 & 100,0 & 41,9 \\
\hline \multicolumn{7}{|l|}{ Faixas etárias } \\
\hline 20 a 29 anos & 16 & 8 & 8 & 2,6 & 2,2 & 50,0 \\
\hline 30 a 39 anos & 91 & 41 & 50 & 13,4 & 12,5 & 45,1 \\
\hline 40 a 49 anos & 102 & 47 & 55 & 15,4 & 14,0 & 46,1 \\
\hline 50 a 59 anos & 263 & 107 & 156 & 35,1 & 36,1 & 40,7 \\
\hline 60 a 69 anos & 175 & 66 & 109 & 21,6 & 24,0 & 37,7 \\
\hline 70 anos ou mais & 81 & 36 & 45 & 11,8 & 11,1 & 44,4 \\
\hline Total & 728 & 305 & 423 & 100,0 & 100,0 & 41,9 \\
\hline
\end{tabular}

Obs.: FTP = faixas de tamanho de posse

* Exceto uma criança pertencente a um não proprietário em 1828. Fontes: Apesp e Livro de registro de batismos de Iguape.

A condição de legitimidade pareceu não influenciar significativamente os resultados já descritos: identificamos 42,5\% das 360 crianças naturais e 41,0\% das 361 legítimas, condição esta manifesta nos assentos de batismo, pertencentes aos proprietários localizados na lista. A mesma observação pode ser feita se considerarmos os padrinhos das crianças. Da combinação com maior ocorrência (qual seja, ambos os padrinhos escravos), localizamos $157(39,7 \%)$ dos 395 cativos batizados. No tocante ao segundo maior grupo, 
formado pelas crianças cativas com os padrinhos livres, encontramos 80 $(45,5 \%)$ dos 176 batizados. $^{31}$

Foi na distribuição entre as diferentes faixas de tamanho das posses que verificamos as maiores diferenças, principalmente com relação às posses com até quatro cativos: dos 70 batizados inseridos nessas menores escravarias encontramos apenas 20 crianças $(28,6 \%)$. Em nenhuma faixa de posse tal proporção alcançou metade dos escravos batizados, porém em todas as com mais de quatro escravos superou os dois quintos, conforme indica a última coluna da tabela 4, proporção esta que passamos a denominar permanência. Assim, entre os grandes proprietários, detentores de 20 ou mais escravos, responsáveis pela maior parte dos batismos $(43,1 \%)$ e das crianças localizadas (41,3\%), verificamos uma permanência de 40,3\%, porcentual que atingiu seu máximo, 49,2\%, nas propriedades com 10 a 19 cativos.

Os resultados expressos no que respeita aos demais atributos delineiam um perfil preponderante dos escravistas responsáveis pela maior parte dos cativos batizados e localizados, qual seja: a maioria do sexo masculino, casado e com idade entre 50 e 69 anos. ${ }^{32}$ Merece destaque o fato de tal segmento apresentar proporções de permanência inferiores aos correlatos e ao índice geral, o que sugere maior atuação dos fatores mortalidade/doações/vendas e seus efeitos sobre os demais proprietários.

Cabe também um comentário sobre a presença ou não, em 1828, dos pais das crianças batizadas. Dos 728 infantes, contingente objeto dos registros paroquiais, verificamos, na lista nominativa, a presença da mãe em 505 (69,4\%) casos; destes, em 235, os filhos estavam também presentes e, em 270, os filhos estavam ausentes. Considerando apenas os legítimos, verificamos a existência do pai em 202 dos 344 casos (em 98 deles coabitavam pai e filhos em 1828). ${ }^{33}$ Em síntese, viviam com pai e mãe 85 das crianças presentes em 1828. A tabela 5 sintetiza os resultados verificados utilizando as mães como referência de organização dos dados.

\footnotetext{
${ }^{31}$ As duas categorias respondem por $80,1 \%$ dos batismos e 80,3\% dos casos localizados. Consideramos, no caso dos padrinhos escravos, o subconjunto daqueles pertencentes à mesma escravaria, totalizando 16,7\% do total de batismos e 15,9\% dos casos localizados (esses porcentuais alçam-se a $23,6 \%$ e $26,3 \%$ se incluirmos os batizados com apenas um dos padrinhos na mesma propriedade).

32 Tal subconjunto congregava, em 1828, 58 proprietários (23,3\%) e 564 escravos arrolados (32,6\%).

33 O valor não corresponde ao total de legítimos (367) por não possuirmos informações sobre alguns pais descritos nos registros como libertos.
} 
Tabela 5

Distribuição de proprietários, mães e crianças cativas segundo número de mães por escravista nos registros de batismos e presença ou não das mães e das crianças na lista nominativa de 1828. Iguape, 1811 a 1828

\begin{tabular}{|c|c|c|c|c|c|c|c|}
\hline \multirow{2}{*}{$\begin{array}{c}\text { Número } \\
\text { de mães }\end{array}$} & \multirow{2}{*}{$\begin{array}{c}\text { Propri- } \\
\text { etários }\end{array}$} & \multicolumn{3}{|c|}{ Mães presentes em 1828 } & \multicolumn{3}{c|}{ Mães ausentes em 1828 } \\
\cline { 3 - 8 } & & N & $\begin{array}{c}\text { Filhos } \\
\text { presentes }\end{array}$ & $\begin{array}{c}\text { Filhos } \\
\text { ausentes }\end{array}$ & N & $\begin{array}{c}\text { Filhos } \\
\text { presentes }\end{array}$ & $\begin{array}{c}\text { Filhos } \\
\text { ausentes }\end{array}$ \\
\hline 1 & 65 & 46 & 41 & 42 & 19 & 16 & 23 \\
\hline 2 & 22 & 28 & 29 & 37 & 16 & 10 & 22 \\
\hline 3 & 17 & 35 & 54 & 46 & 16 & 13 & 21 \\
\hline 4 & 6 & 15 & 26 & 19 & 10 & 8 & 23 \\
\hline 6 & 3 & 9 & 11 & 12 & 6 & 2 & 6 \\
\hline 7 & 6 & 6 & 5 & 10 & 12 & 5 & 17 \\
\hline 10 & 3 & 23 & 27 & 44 & 7 & 5 & 9 \\
\hline Total & 126 & 199 & 235 & 270 & 108 & 68 & 15 \\
\hline & 1 & 9 & 9 & 19 & 9 & 7 & 2 \\
\hline
\end{tabular}

Fontes: Apesp e Livro de registro de batismos de Iguape.

Não deve surpreender o fato de 82,5\% dos proprietários, entre 1811 e 1828, não possuírem mais do que três escravas em suas posses a gerar filhos e estes representarem 48,6\% do total de crianças batizadas e 53,8\% das localizadas, revelando um aspecto acentuado da distribuição da posse de cativos em Iguape. O número médio de filhos por escrava, 2,4 no geral, apresentou uma tendência de expansão seguindo o aumento das propriedades (de 1,9 para 3,0 filhos por escrava); esse mesmo indicador produziu tendência análoga quando consideramos apenas as mães presentes em 1828 (1,8 a 3,1, com 
valor geral igual a 2,5 filhos por escrava). ${ }^{34}$ A permanência entre as mães localizadas revelou-se relativamente mais semelhante entre os distintos grupos, com 49,8\% naquele com até três mães versus 43,4\% nos demais escravistas. Bem menos próximos resultaram os porcentuais associados às mães não localizadas, com permanência de 37,1\% nas pequenas propriedades e 24,6\% nas grandes, não obstante o número médio de filhos bastante similar ao grupo correlato (2,1 contra 2,5 filhos por mãe). Parte de tal resultado deveuse decerto à morte materna (tardia ou não) ${ }^{35}$ e o subsequente efeito na sobrevida dos recém-nascidos. Ademais, não se pode descartar a possibilidade de transferência de propriedade, potencializando o insucesso na localização da mãe e seus filhos segundo a rotina estabelecida neste estudo.

Outra forma de acompanharmos os resultados é a que distribui as mães segundo a quantidade de filhos batizados entre 1811 e 1828. Essa distribuição é fornecida na tabela 6. Praticamente metade das mães apareceu apenas uma vez nos registros de batismos, correspondendo a um quinto do total de assentos. Expandido o grupo para as mães que batizaram até três filhos, atingimos mais de três quartos das mães $(76,5 \%)$ e cerca de metade do total de registros de batismos (49,0\%). ${ }^{36}$ Se confrontarmos os segmentos "mães com até três filhos" e "mães com mais de três filhos", a permanência das crianças pouco varia $(42,3 \%$ e 41,0\%), porém a localização das mães foi significativamente menor no primeiro grupo (61,3\% contra 76,4\%).

Trata-se, esse segmento das "mães com até três filhos", de um grupo heterogêneo, abarcando, de um lado, mães em final de ciclo reprodutivo nos primeiros anos da década de 1810 e, portanto, com seus primeiros rebentos não contemplados por nosso rol de batismos; de outro, mães ainda no início de seu ciclo reprodutivo na segunda metade do decênio posterior; além, é claro, daquelas que provavelmente não superaram a marca de três filhos.

De outra parte, foram 21 os casos de escravas com seis ou mais filhos identificados nos registros de batismo. Além das duas cativas pertencentes

\footnotetext{
34 Se considerarmos apenas os filhos localizados, a média se reduz à metade (1,2 filhos por mãe), com oscilação de 0,8 a 1,5 sem a tendência de crescimento verificada nos valores acima citados.

35 Sobre morte materna tardia, afirma o Ministério da Saúde: "Morte materna tardia é a morte de uma mulher, devido a causas obstétricas diretas ou indiretas, que ocorre num período superior a 42 dias e inferior a um ano após o fim da gravidez". BRASIL. Ministério da Saúde. Secretaria de Atenção à Saúde. Departamento de Ações Programáticas Estratégicas. Manual dos comitês de mortalidade materna. $3^{\text {a }}$ ed. Brasília: Editora do Ministério da Saúde, 2007, p. 12-13.

${ }^{36}$ Esses dois últimos porcentuais alteram-se, respectivamente, para 72,4\% e 49,8\%, se considerarmos apenas os casos localizados.
} 
a Vitorino José Lopes, mencionadas na seção anterior, dois outros proprietários possuíam também, cada um, duas dessas 21 mães: José Antonio Peniche e Francisco Carneiro da Silva Braga.

\section{Tabela 6}

Distribuição de mães e crianças cativas segundo número de filhos por mãe. Iguape, 1811 a 1828

\begin{tabular}{|c|c|c|c|c|c|c|c|c|}
\hline $\begin{array}{l}N^{0} \text { de } \\
\text { filhos }\end{array}$ & $\begin{array}{l}N^{0} \text { de } \\
\text { mães }\end{array}$ & $\begin{array}{l}\text { \% das } \\
\text { mães }\end{array}$ & $\begin{array}{c}\text { Total } \\
\text { de } \\
\text { filhos }\end{array}$ & $\begin{array}{l}\% \text { de } \\
\text { filhos }\end{array}$ & $\begin{array}{c}\text { Mães } \\
\text { localiza- } \\
\text { das }\end{array}$ & $\begin{array}{c}\text { \% das } \\
\text { mães }\end{array}$ & $\begin{array}{l}\text { Filhos } \\
\text { localiza- } \\
\text { dos }\end{array}$ & $\begin{array}{l}\% \text { dos } \\
\text { filhos }\end{array}$ \\
\hline 1 & 148 & 48,2 & 148 & 20,3 & 85 & 42,7 & 59 & 19,5 \\
\hline 2 & 52 & 16,9 & 104 & 14,3 & 32 & 16,1 & 48 & 15,8 \\
\hline 3 & 35 & 11,4 & 105 & 14,4 & 27 & 13,6 & 44 & 14,5 \\
\hline 4 & 29 & 9,4 & 116 & 15,9 & 24 & 12,1 & 50 & 16,5 \\
\hline 5 & 22 & 7,2 & 110 & 15,1 & 15 & 7,5 & 43 & 14,2 \\
\hline 6 & 9 & 2,9 & 54 & 7,4 & 8 & 4,0 & 24 & 7,9 \\
\hline 7 & 6 & 2,0 & 42 & 5,8 & 4 & 2,0 & 20 & 6,6 \\
\hline 8 & 5 & 1,6 & 40 & 5,5 & 3 & 1,5 & 10 & 3,3 \\
\hline 9 & 1 & 0,3 & 9 & 1,2 & 1 & 0,5 & 5 & 1,7 \\
\hline Total & 307 & 100,0 & 728 & 100,0 & 199 & 100,0 & 303 & 100,0 \\
\hline
\end{tabular}

Fontes: Apesp e Livro de registro de batismos de Iguape.

Escolhemos, não obstante, outro proprietário para conformar um derradeiro estudo de caso. O açoriano Antonio Borges Diniz, conforme indicado na tabela 1, constou como dono das crianças em 73 batismos registrados entre 1811 e 1850, representando isoladamente a maior frequência. ${ }^{37}$ Ao realizar seu testamento, em 1861, declarou: “(...) que se algum meu cativo aparecer com carta de liberdade será atendido. Declaro que não libertei alguns mais,

\footnotetext{
37 Se agregarmos a parentela de Diniz (seus dois genros, Francisco Carneiro da Silva Braga e Joaquim José Teixeira dos Santos, além da própria filha viúva, Francisca de Paula Diniz Carneiro) a soma atinge 153 casos ou praticamente 6\% dos batismos aqui analisados.
} 
como são as cativas Margarida (sic), que foi a primeira crioula, que teve sete filhos e estas me teve dado muitas crias, espero que seja bem tratada, digo bem passada em sua velhice". ${ }^{38}$ Encontramos Margarida, preta, natural de Iguape, na lista nominativa de 1815, então com 13 anos. O futuro pai de suas crianças também estava lá: Plácido, igualmente natural de Iguape, 27 anos, negro, provavelmente uma aquisição feita por Diniz a João Antonio da Costa Mendonça que possuía, em 1801, o jovem Plácido, então com nove anos. Entre 1822 e 1842, nasceram as sete crianças, sendo seis meninas. Até 1850, acreditamos que as filhas Catarina (cinco filhos), Felipa (três filhos), Andresa (um filho), Escolástica (dois filhos) e Marina (um filho) constituíram o grande núcleo familiar originado da união entre Plácido e Margarida (descrito na figura 1), totalizando assim 19 dos 73 batismos. Possivelmente, enquanto Borges Diniz redigia seu testamento, Margarida acalentava seus primeiros bisnetos, compondo assim quatro gerações em cativeiro.

Figura 1

Relações familiares e apadrinhamento a partir do casal Margarida e Plácido da propriedade de Antonio Borges Diniz

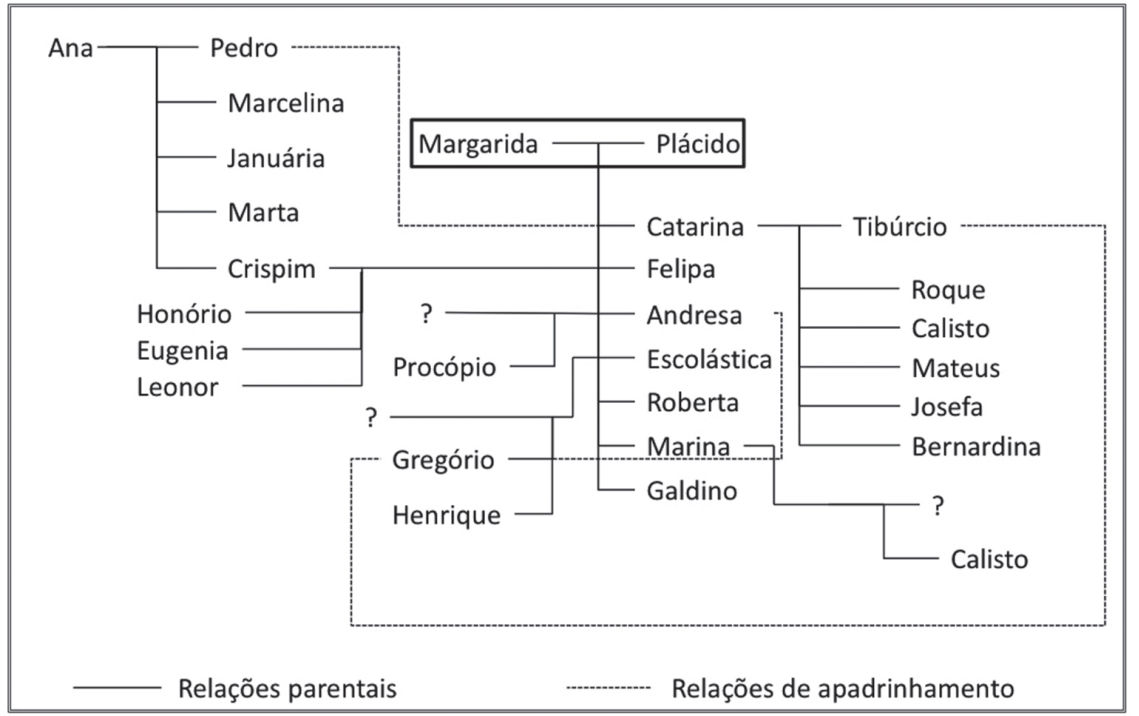

Fontes: Apesp e Livro de registro de batismos de Iguape.

\footnotetext{
${ }^{38}$ Museu Histórico e Arqueológico de Iguape, caixa n. ${ }^{\circ} 102$.
} 
Algumas considerações adicionais parecem pertinentes a partir da análise da figura 1. As filhas Andresa, Marina e Escolástica geraram, pelo menos até 1850, somente filhos naturais. O mesmo vale para Catarina, que aparece casada com Tibúrcio apenas no registro de batismo da última filha, Bernardina. Da mesma forma, Felipa teve o primeiro filho, Honório, ainda sem ligação oficial com Crispim, que aparece posteriormente como pai de Eugenia e Leonor. A irmã de Crispim, Marcelina, teve sua união com Germano sacramentada apenas após o batismo do terceiro dos cincos filhos identificados nos registros paroquiais até 1850. A incidência de mães solteiras ou com regularização tardia da união não foi observada na mesma intensidade na geração de Margarida e Plácido, como se pode inferir com base nos 74,0\% de legítimos entre os escravos batizados de Diniz (cf. tabela 1). Vale dizer, no decurso das sucessivas gerações de escravos que compõem a figura 1, e em especial a partir da metade da década de 1830, notamos a corroboração, para o caso em tela, do movimento apontado anteriormente no início da seção anterior. Naquela altura do texto, com base nos dados do conjunto de assentos de batismo, percebíamos já o aumento da taxa de ilegitimidade observado durante os Oitocentos, de resto evidenciado igualmente por outros estudiosos do passado escravista brasileiro.

Por fim, um breve comentário sobre os padrinhos das crianças cativas de Antonio Borges Diniz. Praticamente três quartos do total de padrinhos e madrinhas eram escravos e outros 13,7\%, livres. Entre os escravos, 52,6\% dos padrinhos e 51,7\% das madrinhas pertenciam à mesma escravaria (ou 77,2\% e 78,3\%, respectivamente, se agregarmos aqueles pertencentes à sua filha e genros). Um resultado quiçá muito mais expressivo sobre as relações de apadrinhamento do que o retrato disponível na figura 1. E talvez mais pulverizado. Além disso, os escravos de Borges Diniz apareceram em outros 73 registros apadrinhando crianças não pertencentes à sua posse, sendo 40 casos com ambos os padrinhos. Entre os mais frequentes proprietários referidos nesses 73 assentos, mencionamos novamente o genro Francisco Carneiro da Silva Braga (23 registros) e os rizicultores Bartolomeu da Costa Almeida Cruz e Vitorino José Lopes, este último já destacado anteriormente, ambos com nove casos.

Convém também fornecermos um breve sumário dos resultados obtidos nesse segundo passo do procedimento que privilegiamos para o cruzamento nominativo dos informes das fontes documentais utilizadas, tal como fizemos para o passo anterior. Desta feita, tomamos como ponto de partida as crianças escravas batizadas de 1811 a 1828 e empreendemos o esforço de identificá-las no arrolamento nominativo deste último ano. Foram mais de três centenas as crianças localizadas, uma proporção de cerca de três décimos do total de infantes batizados no período aludido. Um "rendimento" do 
cruzamento nominativo realizado que nos parece muito bom, não obstante menos significativo que o obtido no primeiro passo de nosso procedimento, no qual o ponto de partida para o cruzamento nominativo esteve na lista de 1828 (localizamos então, vale lembrar mais uma vez, pouco mais de metade do contingente de crianças recenseadas procuradas nos assentos paroquiais).

Ademais, corroborando nossas expectativas, o referido "rendimento" mostrou-se condicionado pela proximidade temporal entre as datas dos batismos e o ano do recenseamento selecionado, 1828. Vale dizer, foi maior a possibilidade de encontrarmos, na lista de 1828, crianças escravas (e seus proprietários) cujos batizados haviam sido registrados na década de 1820, em comparação àquelas cujo primeiro sacramento fora assentado no decênio de 1810. De fato, se tomarmos apenas os batizados registrados de 1822 a 1828, o "rendimento" atinge proporção muito próxima à verificada no passo anterior do cruzamento efetuado (49,7\% versus 53,9\%).

A localização das mais de três centenas de crianças referidas no parágrafo anterior não se mostrou influenciada por sua condição de legitimidade. Por outro lado, o tamanho das escravarias apareceu como um fator importante a condicionar o sucesso do cruzamento realizado. De fato, os porcentuais atingidos pela identificação dos pequenos batizandos na lista nominativa foram menores nas posses formadas por menos cativos. O perfil dominante dos escravistas detentores da maioria dos escravos batizados e localizados no arrolamento indicia a maior estabilidade de suas escravarias: eram amiúde homens casados e na faixa etária de 50 a 69 anos. E, ainda que a maior parte das mães escravas apareça nos assentos paroquiais apenas uma vez, foram relevantes as proles numerosas, a exemplo do caso estudado com mais detalhe, o casal Margarida e Plácido, pertencentes a Antonio Borges Diniz e pais de sete crianças.

\section{Considerações finais}

Neste artigo estudamos um conjunto de crianças escravas. Por conseguinte, incursionamos em vários temas objeto da atenção da historiografia da escravidão no Brasil. Família escrava, compadrio dos bebês nascidos no cativeiro, estrutura da posse de cativos são decerto alguns dos tópicos que mais se evidenciam em nossa análise. Esses tópicos são tratados, de início, com base em um panorama geral elaborado a partir dos mais de 2.500 batizados de crianças escravas registrados em Iguape, localidade paulista situada no Vale do Ribeira, no período de 1811 a 1850. A distribuição dos registros ao longo das décadas contempladas, a condição de legitimidade 
das crianças batizadas, o intervalo temporal entre o nascimento e o batismo, são as principais variáveis analisadas, sempre sopesadas pela consideração do pano de fundo econômico dado pelo evolver da rizicultura na região. Assim, por exemplo, foi interessante observar, na etapa de maior expansão da mencionada cultura, tomada a distribuição mês a mês, a sobreposição entre concentração dos batismos de crianças escravas e as maiores quantidades de arroz exportadas pelo porto de Iguape.

Em seguida, conformando os distintos passos que traduzem o principal objetivo de nosso estudo, exploramos duas possibilidades analíticas decorrentes do cruzamento dos informes constantes dos assentos de batismo com os das listas nominativas de habitantes da aludida vila, em especial a de 1828. Na primeira vertente explorada, partimos do conjunto das crianças cativas com menos de 10 anos de idade arroladas na lista e averiguamos sua presença ou não na documentação paroquial. Na segunda vertente, percorremos o caminho inverso. Partimos do contingente dos escravos batizados de 1811 a 1828 e, com o auxílio da identidade de seus proprietários e eventualmente da identidade dos herdeiros desses escravistas, averiguamos sua presença ou não no recenseamento de 1828.

Foram muitas as inferências proporcionadas pelos dois passos acima descritos, sumariadas, na seção anterior, ao término da apresentação de cada um deles. Parte de tais inferências resultou da constante consideração da variável faixa de tamanho das posses cativas. Percebemos, por exemplo, os vínculos entre o dito tamanho, o ciclo de vida dos proprietários e o próprio sucesso maior ou menor na identificação das pessoas pelo cruzamento das fontes utilizadas. Foi igualmente profícuo o acompanhamento mais minucioso de casos selecionados, a exemplo de Antonio Borges Diniz e de sua escravaria, capazes de contribuir para o esclarecimento das nuances das relações dos escravos entre si e deles com as pessoas livres, todos juntos protagonistas na construção de nossa sociedade pretérita.

\section{Referências bibliográficas}

BACELLAR, Carlos de Almeida Prado. Os compadres e as comadres de escravos: um balanço da produção historiográfica brasileira. In: XXVI SIMPÓSIO NACIONAL DE HISTÓRIA - ANPUH. Anais. São Paulo, 2011. Disponível em:

<http://www.snh2011.anpuh.org/resources/anais/14/1307925540_ARQUIVO_Oscompadreseascomadresdeescravos.pdf $>$. Acesso em: 07/02/2013.

BRASIL. Ministério da Saúde. Secretaria de Atenção à Saúde. Departamento de Ações Programáticas Estratégicas. Manual dos comitês de mortalidade materna. $3^{\text {a }}$ ed. Brasília: Editora do Ministério da Saúde, 2007. 
rev. hist. (São Paulo), n. 171, p. 141-174, jul.-dez., 2014 http://dx.doi.org/10.11606/issn.2316-9141.rh.2014.89010
Agnaldo Valentin e José Flávio Motta

0 primeiro sacramento - batismos de escravos em Iguape (1811-1850)

CARNEIRO, Marina Braga; CHAGAS, Paula Roberta; NADALIN, Sergio Odilon. Nascer e garantir-se no reino de Deus; Curitiba, séculos XVIII e XIX. Revista Brasileira de Estudos Populacionais, v. 27, n. 2, jul./dez. 2010, p. 361-384.

CARVALHO, Marcus Joaquim Maciel de. A repressão do tráfico atlântico de escravos e a disputa partidária nas províncias: os ataques aos desembarques em Pernambuco durante o governo praieiro, 1845-1848. Tempo, v. 14, $\mathrm{n}^{\mathrm{o}} .27$. Niterói-RJ, 2009, p. 133-149.

Coleção de leis do Império do Brasil, 1808-1889. Disponível em:

$<$ http://www2.camara.gov.br/legislacao/publicacoes/doimperio>. Acesso em 19/05/2008.

CUNHA, Maísa Faleiros da. Demografia e família escrava. Franca -SP, século XIX. Tese de doutorado, Demografia, Unicamp. Campinas, 2009.

FARIA, Sheila de Castro. A colônia em movimento: fortuna e família no cotidiano colonial. Rio de Janeiro: Nova Fronteira, 1998.

LIMA, Carlos Alberto Medeiros. A cana, o café, os alimentos e o tráfico ilegal de escravos para a província de São Paulo. Programa de Seminários em História Econômica "Hermes \& Clio". São Paulo: FEA/USP, junho de 2011. Disponível em: http://www.fea.usp.br/feaecon//nucleos_ex.php?i=9\&्e=18.

LUNA, Francisco Vidal et al. Escravismo em São Paulo e Minas Gerais. São Paulo: Edusp; Imprensa Oficial do Estado de São Paulo, 2009.

MAMIGONIAN, Beatriz Gallotti. In the name of freedom: Slave trade abolition, the law and the Brazilian branch of the African emigration scheme (Brazil-British West Indies, 1830s-1850s). Slavery \& Abolition, v. 30, nº. 1, março 2009, p. 41-66.

MAMIGONIAN, Beatriz Gallotti \& GRINBERG, Keila (orgs.). Dossiê: "Para inglês ver?" Revisitando a Lei de 1831. Estudos Afro-Asiáticos, ano 29, no ${ }^{\circ}$. 1/ 2/ 3. Rio de Janeiro, jan./dez. 2007, p. 90-340.

MARCÍLIO, Maria Luiza. Mortalidade e morbidade da cidade do Rio de Janeiro imperial. Revista de História, no 127-128, ago-dez/1992 a jan-jun/1993, p. 53-68.

MARQUES, Manuel Eufrásio de Azevedo. Apontamentos históricos, geográficos, biográficos, estatísticos e noticiosos da Província de São Paulo, seguidos da cronologia dos acontecimentos mais notáveis desde a fundação da Capitania de São Vicente até o ano de 1876, 2 v. São Paulo: Comissão do IV Centenário da Cidade de São Paulo, 1953.

MOTTA, José Flávio. Corpos escravos, vontades livres: posse de escravos e família escrava em Bananal (1801-1829). São Paulo: Fapesp, Annablume, 1999.

MOTTA, José Flávio \& VALENTIN, Agnaldo. Dinamismo econômico e batismo de ingênuos - a libertação do ventre da escrava em Casa Branca e Iguape, Província de São Paulo (1871-1885). Estudos Econômicos, v. 38, n. 2, abr./jun. 2008, p. 211-234.

VALENTIN, Agnaldo. Uma civilização do arroz: agricultura, comércio e subsistência no Vale do Ribeira (1800-1880). Tese de doutorado, História, FFLCH-USP. São Paulo, 2006.

VASCONCELLOS, Marcia Cristina Roma de. Famílias escravas em Angra dos Reis, 18011888. Tese de doutorado, História, FFLCH-USP. São Paulo, 2006. 